\title{
Ocean Acidification from Below in the Tropical Pacific
}

\author{
Ishii Masao ${ }^{1,}{ }^{*}$, Rodgers Keith B. ${ }^{2,3}$, Inoue Hisayuki Y. 4, Toyama Katsuya ${ }^{1}$, Sasano Daisuke 1, 5 , \\ Kosugi Naohiro ${ }^{1}$, Ono Hisashi ${ }^{1}$, Enyo Kazutaka ${ }^{5}$, Nakano Toshiya ${ }^{5}$, ludicone Daniele ${ }^{6}$, \\ Blanke Bruno ${ }^{7}$, Aumont Olivier ${ }^{8}$, Feely Richard A. ${ }^{9}$
}

\begin{abstract}
${ }^{1}$ Meteorological Research Institute, Japan Meteorological Agency Tsukuba ,Japan
${ }^{2}$ Center for Climate Physics Institute for Basic Science Busan ,South Korea

${ }^{3}$ Pusan National University Busan ,South Korea

${ }^{4}$ Graduate School of Environmental Earth Sciences Hokkaido University Sapporo ,Japan

5 Global Environment and Marine Department, Japan Meteorological Agency Tokyo, Japan

${ }^{6}$ Department of Integrated Marine Ecology, Stazione Zoologica Anton Dohrn Naples, Italy

7 Laboratoire d'Océanographie Physique et Spatiale, UMR 6523 CNRS-Ifremer-IRD-UBO, Institut

Universitaire Européen de la Mer Brest, France

${ }^{8}$ Laboratoire d'Océanographie et du Climat: Expérimentations et Approches Numériques (LOCEAN), Centre IRD de Bretagne Plouzané ,France

${ }^{9}$ Pacific Marine Environmental Laboratory, National Oceanic and Atmospheric Administration, Seattle Washington ,USA
\end{abstract}

* Corresponding author : Masao Ishii, email address : mishii@mri-ima.go.jp

\begin{abstract}
:
Identifying ocean acidification and its controlling mechanisms is an important priority within the broader question of understanding how sustained anthropogenic $\mathrm{CO} 2$ emissions are harming the health of the ocean. Through extensive analysis of observational data products for ocean inorganic carbon, here we quantify the rate at which acidification is proceeding in the western tropical Pacific Warm Pool, revealing $-0.0013 \pm 0.0001 \mathrm{yr}-1$ for $\mathrm{pH}$ and $-0.0083 \pm 0.0007 \mathrm{yr}-1$ for the saturation index of aragonite for the years $1985-2016$. However, the mean rate of total dissolved inorganic carbon increase $(+0.81 \pm 0.06 \mu \mathrm{mol} \mathrm{kg}-1$ yr-1) sustaining acidification was $\sim 20 \%$ slower than what would be expected if it were simply controlled by the rate of atmospheric $\mathrm{CO} 2$ increase and transmitted through local air-sea $\mathrm{CO} 2$ equilibration. Joint Lagrangian and Eulerian model diagnostics indicate that the acidification of the Warm Pool occurs primarily through the anthropogenic $\mathrm{CO} 2$ that invades the ocean in the extra-tropics, is transported to the tropics through the thermocline shallow overturning circulation, and then re-emerges into surface waters within the tropics through the Equatorial Undercurrent from below. An interior residence time of several years to decades, acting in conjunction with the accelerating $\mathrm{CO} 2$ growth in the atmosphere, can be expected to contribute to modulating the rate of Warm Pool acidification.
\end{abstract}




\section{Key Points}

- Progress of ocean acidification in the western tropical Pacific Warm Pool was identified using the data of oceanic $\mathrm{CO} 2$ measurements The rate of oceanic CO2 increase here was $\sim 20 \%$ lower than that expected from the growth rate of the mixing ratio of $\mathrm{CO} 2$ in the atmosphere Inter-gyre exchange of anthropogenic $\mathrm{CO} 2$ within the thermocline predominantly controls the rate of acidification in this region

Keywords : Ocean acidification, Western tropical Pacific Warm Pool, Equatorial Undercurrent, Shallow meridional overturning circulations 


\section{Introduction}

The western tropical Pacific is a realm of rich marine biodiversity that accommodates a highly diverse range of coral reef habitats (WorldFish, 2019) (Figure 1a). It contains $75 \%$ of all known coral species and more than 3000 species of fish and supports the livelihood of more than 110 million people for whom the associated marine ecosystems provide food, income and safety through their sustained ecosystem services (Burke et al., 2011). However, the region has been degraded by multiple adverse human activities including overfishing, habitat destruction, and land-sourced pollution (Roberts et al., 2002; Burke et al., 2012). Importantly, coral reef habitats are also thought to have been under increasing stress due to ocean acidification (Kleypas et al., 1999, Langdon et al., 2003, Hoegh-Guldberg, 2007, Pandolfi et al., 2011), i.e., the increase of hydrogen ion concentration (reduction of $\mathrm{pH}$ ) and decrease of the saturation level of calcium carbonate minerals in seawater over an extended period of time due to the excess $\mathrm{CO}_{2}$ uptake from the atmosphere. Together with global warming and associated trends toward sea-level rise and episodic bleaching events, ocean acidification has been driven by increasing $\mathrm{CO}_{2}$ emissions associated with human activities. Even if anthropogenic $\mathrm{CO}_{2}$ emissions are substantially reduced over the coming decades, the trend toward acidification is expected to continue to pose risks for calcifying organisms such as corals and mollusks that show greater sensitivity of their growth to ocean acidification (Gattuso et al., 2015). This will have serious large-scale consequences for marine ecosystems and undermine shoreline protection from storm damage and erosion (Albright et al., 2018). The resulting socio-economic impacts anticipated in and around the western tropical Pacific motivate a quantification and attribution of the evolution of ocean acidification in recent decades over this region.

Measurements of the partial pressure of $\mathrm{CO}_{2}$ in surface seawater $\left(p \mathrm{CO}_{2} \mathrm{sw}\right)$ and in the atmosphere ( $p \mathrm{CO}_{2}$ air) have been frequently made in the western tropical Pacific since the mid-1980s. In the mid1990 s to late $2000 \mathrm{~s}$, these data revealed a trend toward increasing $p \mathrm{CO}_{2} \mathrm{sw}$ with the rate having varied over the period of analysis (Inoue et al., 1995, Feely et al., 1999, 2006, Takahashi et al., 2003, Ishii et al., 2009, 2014). More recently, international efforts toward data synthesis and quality-control have begun for $p \mathrm{CO}_{2} \mathrm{Sw}$ in the surface layer (Pfeil et al., 2013, Bakker et al., 2016) and other inorganic carbon 
variables such as total dissolved inorganic carbon (DIC) and total alkalinity (TA) in the surface layer and in the ocean interior (Key et al., 2004, Tanhua et al., 2010, Suzuki et al., 2013, Olsen et al., 2016).

Such efforts have enabled continuing integration of data from multiple sources and platforms, thereby providing an account of changes in the oceanic $\mathrm{CO}_{2}$ chemistry for both surface and ocean interior waters for a prolonged period extending over the past three decades in a large part of the global oceans as well as in the western tropical Pacific. In addition, the development of Lagrangian diagnostic tools with forward ocean models (e.g., Blanke and Grima, 2011) provides an opportunity to explore the transports of water masses and anthropogenic carbon, and potential nonlocal large-scale ocean circulation pathways that can sustain regional acidification.

\section{Data and Methods}

\subsection{Analyses of Multi-decadal Trends in the Surface Layer of the Warm Pool}

For the observational data analyses in this work, we defined the western tropical Pacific Warm Pool as surface water characterized by $T>28.7^{\circ} \mathrm{C}$ and $S<34.6$ within the $130^{\circ} \mathrm{E}-180^{\circ} \mathrm{E}, 5^{\circ} \mathrm{S}-5^{\circ} \mathrm{N}$ zonal band. In the central and eastern tropical Pacific, the equatorial divergence brings colder and more saline subsurface waters rich in dissolved inorganic carbon (DIC) and nutrients to the surface, with substantial variability in this region also impacting ocean biogeochemistry. The zone of equatorial divergence expands to the western tropical Pacific during the cold phase of the El Niño Southern Oscillation (Supplementary Figure 1) (Ishii et al., 2004, 2014). By contrast, nitrate is depleted and the stratification minimizes the direct impact of the equatorial divergence on the variability of inorganic carbon variables in the Warm Pool. Seasonal as well as interannual variability in inorganic carbon and associated variables is much smaller in the Warm Pool than in the eastern divergence zone (Ishii et al., 2004). It is therefore expected that the trend toward ocean acidification as a result of the increasing anthropogenic $\mathrm{CO}_{2}$ invasion into the ocean is detectable with observations extending over decades in the Warm Pool.

We used Warm Pool $p \mathrm{CO}_{2} \mathrm{sw}$ data acquired in a total of 145 cruises conducted since the year 1985 
(Supplementary Table 1). Out of a total of 114 cruises, measurements were made by the Meteorological Research Institute or the Global Environment and Marine Department of Japan Meteorological Agency (JMA) on board JMA's RVs Ryofu Maru II and III, and Keifu Maru II (89 cruises; http://www.data.jma.go.jp/gmd/kaiyou/db/vessel_obs/data-report/html/ship/ship_e.php), on board the $R V$ Natsushima, the $R V$ Kaiyo, and the $R V$ Mirai of the Japan Agency for Marine-Earth Science and Technology (JAMSTEC) (21 cruises; http://www.godac.jamstec.go.jp/darwin/e), and on board the University of Tokyo's $R V$ Hakuho Maru (4 cruises). In these cruises, an automated underway $p \mathrm{CO}_{2}$ system equipped with a showerhead-type equilibrator and a non-dispersive infrared $\mathrm{CO}_{2}$ analyzer (Inoue et al., 2000) was used for the measurements. Mixing ratio of $\mathrm{CO}_{2}$ in the air of the marine boundary layer have also been measured during these cruises. During 17 cruises conducted between the 1980s and the early 1990s, underway salinity measurements were not carried out and the salinity of surface waters collected at hydrographic stations was therefore used for analysis. Among the other 31 cruises, $p \mathrm{CO}_{2} \mathrm{sw}$ data were also collected using automated underway systems with different showerhead-type equilibrators (e.g., Poisson et al., 1993, Wanninkhof and Thoning, 1993, Wong et al., 1993, Feely et al., 1998) in 30 cruises, mainly by the US National Oceanic and Atmospheric Administration, and using "rotating disk equilibrator" in one cruise (Sabine et al., 1999). All these data are available in the SOCAT database (Bakker et al., 2016) (https://www.socat.info/index.php/dataaccess/).

We analyzed the variability of TA based mainly on TA data calculated from $p \mathrm{CO}_{2} \mathrm{sw}$ and DIC. Underway measurements of DIC in the western tropical Pacific were performed using a high-precision coulometric technique in conjunction with $p \mathrm{CO}_{2} \mathrm{Sw}$, temperature and salinity in 12 cruises of the $R V$ Kaiyo, the $R V$ Mirai and the $R V$ Hakuho Maru over 1994-2003 (Ishii et al., 2004) (http://www.godac.jamstec.go.jp/darwin/e). In 31 other cruises conducted in 1994-2016 by the JMA, DIC measurements were made in surface layers at hydrographic stations (http://www.data.jma.go.jp/gmd/kaiyou/db/vessel_obs/data-report/html/ship/ship_e.php). For this total of 43 cruises, TA in surface water was calculated from $p \mathrm{CO}_{2} \mathrm{sw}$, DIC, temperature and salinity data 
using the concentrations of conservative constituents and equilibrium constants recommended by Dickson et al. (2007) including $\mathrm{CO}_{2}$ solubility in sea water (Weiss, 1974), dissociation constants for carbonic acid (Lueker et al., 2000) and those for bisulfate ion (Dickson, 1990) and hydrogen fluoride (Dickson and Riley, 1979). The calculations were performed with the Microsoft Excel version of "CO2SYS" (Lewis and Wallace, 1998) modified for use with the carbonic acid dissociation constants given by Lueker et al. (2000). No significant offset was found between the calculated TA and measured TA and calculated TA for data measured by JMA after 2010; the average and standard deviation of the difference in TA (measured - calculated) was $+0.4 \pm 3.7 \mu \mathrm{mol} \mathrm{kg}^{-1}(\mathrm{n}=92)$ where \pm 3.7 is a standard deviation. The analysis also used quality-controlled TA data from 10 other cruises in the western tropical Pacific conducted by other organizations since 1992. These data have been incorporated into the
GLODAPv2
database
(Olsen
et
al.,

2019)

(https://www.nodc.noaa.gov/ocads/oceans/GLODAPv2_2019/).

TA in the surface layer is known to show little spatial variability over tropical and subtropical zones of the western Pacific when corrected for the dilution and concentration of seawater by precipitation and evaporation by normalizing to a constant salinity value (Millero et al., 1998; Takatani et al., 2014). In this work, salinity-normalized TA at $S=35(\mathrm{sTA}=\mathrm{TA} \cdot 35 / S)$ averaged over the western tropical Pacific during the years 1992-2016 was $2297.2 \pm 3.7 \mu \mathrm{mol} \mathrm{kg}^{-1}(\mathrm{n}=71)$ and showed an indistinct rate of increase $\left(+0.25 \pm 0.06 \mu \mathrm{mol} \mathrm{kg}^{-1} \mathrm{yr}^{-1}, \mathrm{n}=71\right)$ over the Warm Pool during the years 1992-2016 (Figure 1c). The low variability of sTA in the western tropical Pacific over space and time $( \pm 3.7 \mu \mathrm{mol}$ $\mathrm{kg}^{-1}$ ) compares well with the uncertainty of the TA analysis, nominally $6 \mu \mathrm{mol} \mathrm{kg}{ }^{-1}$ (Tanhua et al., 2010). Therefore, we assume that sTA in surface layer remained unchanged $\left(2297.2 \pm 3.7 \mu \mathrm{mol} \mathrm{kg}^{-1}\right)$ over the last three decades since the mid-1980s. Then, values of salinity-normalized DIC (sDIC $=$ DIC $\cdot 35 / S)$, $\mathrm{pH}$ (in total hydrogen ion concentration scale), and saturation indices of calcium carbonate minerals calcite $\left(\Omega_{\text {cal }}\right)$ and aragonite $\left(\Omega_{\text {ara }}\right)$ at in-situ temperature and salinity $\left(\Omega=\left[\mathrm{Ca}^{2+}\right]\left[\mathrm{CO}_{3}{ }^{2-}\right] \cdot K_{\mathrm{sp}}{ }^{-1}\right.$ where $K_{\mathrm{sp}}$ is the apparent solubility product of calcite or aragonite (Mucci, 1983)) were calculated from $p \mathrm{CO}_{2} \mathrm{Sw}$, temperature and salinity data at a constant value of sTA $=2297.2 \mu \mathrm{mol} \mathrm{kg}^{-1}$ using the same equilibrium 
constants and the same algorithms as for the calculation of nTA from $p \mathrm{CO}_{2} \mathrm{Sw}$ and nDIC. Finally, their monthly mean values in the Warm Pool were calculated for the months when measurements have been made, and were used to analyze their rates of change and standard errors by a linear least-squares method. Each data plot and error bar shown in Fig. $1 \mathrm{~b}$ to Fig. $1 \mathrm{~g}$ denotes monthly mean values and standard deviations.

\subsection{Trend analyses in the Equatorial Undercurrent}

For the analyses of multi-decadal trends in the Equatorial Undercurrent (EUC), we used hydrographic and biogeochemical data including DIC and TA at depths that have been measured in a narrow equatorial band of the western tropical Pacific $\left(1^{\circ} \mathrm{S}-1^{\circ} \mathrm{N}, 130^{\circ} \mathrm{E}-180^{\circ}\right)$. They have been collected over a total of 53 cruises (53 for DIC and 27 for TA) over 1992-2016 including 32 cruises of the JMA and 13 cruises of JAMSTEC (see Supplementary Table 1). Data from cruises conducted over 1992-2008, i.e., 37 cruises for DIC and 13 cruises for TA, were quality-controlled and stored in the PACIFICA databases (Suzuki et al., 2013) (https://www.nodc.noaa.gov/ocads/oceans/PACIFICA/). Additional measurements during 2009-2016 were taken by JMA over $142^{\circ} \mathrm{E}-165^{\circ} \mathrm{E}$ (http://www.data.jma.go.jp/gmd/kaiyou/db/vessel_obs/data-report/html/ship/ship.php). All these data are also available online from GLODAPv2_2019 (Olsen et al., 2019).

A secular trend of increasing DIC following anthropogenic $\mathrm{CO}_{2}$ invasion into the ocean is detectable as an upward trend of preformed DIC $\left(\mathrm{DIC}^{\circ}\right)$, which is the DIC concentration when the water parcel was in last contact with the atmosphere in the surface layer and is represented as:

$$
\begin{aligned}
\mathrm{DIC}^{\mathrm{o}}= & \mathrm{DIC}^{\mathrm{opi}}+C_{\text {ant }} \\
& =\mathrm{DIC}^{\mathrm{m}}-\Delta C_{\text {bio }}=\mathrm{DIC}^{\mathrm{m}}-\Delta C_{\text {org }}-\Delta C_{\text {carb }}
\end{aligned}
$$

DIC $^{\text {opi }}$ refers to preformed DIC in the preindustrial era that is assumed to be in steady state and $C_{\text {ant }}$ the anthropogenic $\mathrm{CO}_{2}$ component in DIC that increases over time. $\mathrm{DIC}^{\mathrm{m}}$ is the DIC measured in the ocean 
interior and $\Delta C_{\text {bio }}$ is the correction term for biological activity subsequent to subduction in the formation region. The term $\Delta C_{\text {bio }}$ is decomposed into the components representing respiration by organisms (remineralization of organic matter), $\Delta C_{\mathrm{org}}$, and the dissolution of carbonate particles, $\Delta C_{\text {carb }}$, where $\Delta C_{\text {org }}=r_{\mathrm{C} / \mathrm{O} 2} \cdot \mathrm{AOU}$, and $\Delta C_{\text {carb }}=0.5 \cdot\left(\mathrm{TA}^{\mathrm{m}}+r_{\mathrm{N} / \mathrm{O} 2} \cdot \mathrm{AOU}-\mathrm{TA}^{\circ}\right)($ Gruber et al., 1996). Here, $\mathrm{AOU}$ refers to the apparent oxygen utilization, i.e., the difference between the measured dissolved oxygen concentration and its saturation concentration under the same potential temperature and salinity conditions (Garcia and Gordon, 1992). $\mathrm{TA}^{\mathrm{m}}$ and $\mathrm{TA}^{\mathrm{o}}$ are TA measured at depths and preformed TA that has been empirically expressed as a function of potential temperature and other ocean variables (Sabine et al., 2002), respectively. The coefficients $r_{\mathrm{C} / \mathrm{O} 2}$ and $r_{\mathrm{N} / \mathrm{O} 2}$ are the stoichiometric $\mathrm{C} /-\mathrm{O}_{2}$ and $\mathrm{N} /-\mathrm{O}_{2}$ remineralization ratios. We used $117 / 170$ for $r_{\mathrm{C} /-\mathrm{O} 2}$ and $16 / 170$ for $r_{\mathrm{N} /-\mathrm{O} 2}$, following the stoichiometric $\Delta \mathrm{P} / \Delta \mathrm{N} / \Delta \mathrm{C}_{\text {org }} /-\Delta \mathrm{O}_{2}$ ratios of $1 /(16 \pm 1) /(117 \pm 14) /(170 \pm 10)$ determined by Anderson and Sarmiento (1994). We also tested $r_{\mathrm{C} / \mathrm{O} 2}$ of $131 / 160$ and $103 / 180$ and $r_{\mathrm{N} / \mathrm{O} 2}$ of $17 / 160$ and $15 / 180$ to see the sensitivity of DIC change to the choice of $r_{\mathrm{C} /-\mathrm{O} 2}$ and $r_{\mathrm{N} / \mathrm{O} 2}$. Remineralization of organic matter by denitrification is another process contributing to $\Delta C_{\text {bio }}$ (Sabine et al., 2002). However, we have ignored its contribution in equation (1), because the contribution of denitrification to DIC changes is considered to be very small over the water column in the western tropical Pacific (Deutsch et al., 2001). Trends of $\mathrm{DIC}^{\mathrm{o}}$ are also modulated by dilution and concentration of surface water due to precipitation and evaporation. Therefore, we examined the $\mathrm{DIC}^{\mathrm{o}}$ trend that was normalized to a reference salinity of 35 $\left(\mathrm{sDIC}^{\circ}\right)$. The rate of $\mathrm{sDIC}^{\mathrm{o}}$ change was then determined by decomposing it into two terms in equation (1) as the rate of DIC change corrected for respiration, $\mathrm{DIC}^{\mathrm{m}}-\Delta C_{\mathrm{org}}$, and that associated with the dissolution of carbonate particles, $\Delta C_{\text {carb }}$.

The trend toward increasing sDIC ${ }^{\circ}$ was analyzed in the thermocline (i.e., in the Equatorial Undercurrent, EUC) and below on potential density horizons spanning $\sigma_{\theta}=23.0$ to $27.7 \mathrm{~kg} \mathrm{~m}^{-3}$ (at $\sim 2000$ $\mathrm{m})$ in the narrow equatorial band $1^{\circ} \mathrm{S}-1^{\circ} \mathrm{N}$ over $130^{\circ} \mathrm{E}-180^{\circ}$. In the thermocline, both $\mathrm{DIC} \mathrm{C}^{\mathrm{m}}-\Delta C_{\mathrm{org}}$ and temperature exhibit large gradients with depth but vertical resolution of discrete water samplings are not sufficient to resolve the vertical profiles well by themselves. Consequently, values of $\mathrm{sDIC}^{\mathrm{o}}$ on 
isopycnal horizons have potentially large errors when they are obtained from the interpolated profiles of sDIC $^{\circ}$ with respect to depth. To reduce their errors associated with the vertical interpolation, we examined the relationship $\mathrm{DIC}^{\mathrm{m}}-\Delta C_{\mathrm{org}}, \mathrm{TA}^{\mathrm{m}}+r_{\mathrm{N} / \mathrm{O} 2} \cdot \mathrm{AOU}$, and $\mathrm{TA}^{\mathrm{o}}$, respectively, with respect to potential density $\left(\sigma_{\theta}\right)$ (Supplementary Figure 2), and they were fitted with a function of $\sigma_{\theta}$ and observation time by multiple regression analysis:

$$
X=c_{0}+c_{1} \cdot y r+c_{2} \cdot\left(\sigma_{\theta}-\sigma_{\theta}{ }^{\text {ref }}\right)+c_{3} \cdot\left(\sigma_{\theta}-\sigma_{\theta}{ }^{\text {ref }}\right)^{2}+\varepsilon
$$

where $X$ denotes $\mathrm{DIC}^{\mathrm{m}}-\Delta C_{\mathrm{org}}, \mathrm{TA}^{\mathrm{m}}+r_{\mathrm{N} / \mathrm{O} 2} \cdot \mathrm{AOU}$, or $\mathrm{TA}^{\circ}$ normalized at $S=35, y r=$ year -2000 and $\varepsilon$ represents the residual of the fit. The fit was performed on eight density layers which represent a modest restructuring of the coarse-grained layering presented in a previous study (Sloyan et al., 2003) including Upper Thermocline Water (UTW: $23.0-24.5 \mathrm{~kg} \mathrm{~m}^{-3}$ ), Central Thermocline Water (CTW: $24.5-25.5 \mathrm{~kg}$ $\mathrm{m}^{-3}$ ), Lower Thermocline Water (LTW: $25.5-26.3 \mathrm{~kg} \mathrm{~m}^{-3}$ ), Thermostad Water (TSW: 26.3-26.6 kg m ${ }^{3}$ ), Mode Water (MW: 26.6-26.9 $\mathrm{kg} \mathrm{m}^{-3}$ ), Upper Intermediate Water (UIW: 26.9-27.2 $\mathrm{kg} \mathrm{m}^{-3}$ ), Lower Intermediate Water (LIW: 27.2-27.5 $\mathrm{kg} \mathrm{m}^{-3}$ ), and Upper Deep Water (UDW: 27.5-27.7 $\mathrm{kg} \mathrm{m}^{-3}$ ). Represented as $\sigma_{\theta}{ }^{\text {ref }}$ in equation (2) is the reference potential density (mid-point of the density range) for each layer.

Regression analysis was repeated three times for $\mathrm{DIC}^{\mathrm{m}}-\Delta C_{\text {org }}$ and twice for $\mathrm{TA}^{\mathrm{m}}+r_{\mathrm{N} / \mathrm{O} 2} \cdot \mathrm{AOU}$ and $\mathrm{TA}^{\circ}$, while rejecting data outside $\pm 2 s$. Data of $\mathrm{DIC}^{\mathrm{m}}-\Delta C_{\mathrm{org}}$, and $\mathrm{TA}^{\mathrm{m}}+r_{\mathrm{N} / \mathrm{O} 2} \cdot \mathrm{AOU}$ and $\mathrm{TA}^{\mathrm{o}}$ were then normalized to the values at $\sigma_{\theta}^{\text {ref }}$ in each density class using equation (3):

$$
X^{\mathrm{ref}}=X-c_{2} \cdot\left(\sigma_{\theta}-\sigma_{\theta}^{\mathrm{ref}}\right)-c_{3} \cdot\left(\sigma_{\theta}-\sigma_{\theta}{ }^{\mathrm{ref}}\right)^{2}
$$

Finally, cruise-mean values of $\left(\mathrm{DIC}^{\mathrm{m}}-\Delta C_{\mathrm{org}}\right)^{\mathrm{ref}},\left(\mathrm{TA}^{\mathrm{m}}+r_{\mathrm{N} / \mathrm{O} 2} \cdot \mathrm{AOU}\right)^{\mathrm{ref}}$, and $\mathrm{TA}^{\text {oref }}$ were calculated and fitted with a linear function of time for each density class to evaluate the rate of $\mathrm{sDIC}^{\circ}$ change. Equations (2) and (3) were also applied to the data of potential temperature and salinity to evaluate their trends in each density layer in the EUC and below. 


\subsection{Lagrangian Backward Tracking for the Source Waters of the Warm Pool}

Through a series of diagnostics (including Lagrangian) performed on a forward ocean carbon

cycle model, we examine anthropogenic $\mathrm{CO}_{2}$ ventilation and re-emergence pathways and associated transit timescales by highlighting the source waters of the Warm Pool. To do this, we apply the Ariane Lagrangian diagnostic tool kit (Blanke and Grima, 2011) to interpret the model output using circulation fields from a cyclostationary normal-year-forced ORCA2-LIM run that included the PISCES ocean biogeochemistry model run offline (Iudicone et al., 2016). The PISCES component of the model configuration has been run with both the observed anthropogenic $\mathrm{CO}_{2}$ transient and a preindustrial atmospheric $\mathrm{CO}_{2}$ boundary, thus facilitating a definition of anthropogenic carbon as the difference between them. For the anthropogenic $\mathrm{CO}_{2}$ transient thus defined, the model output exhibits a robust correspondence with observational constraints for the year 1995 (Iudicone et al., 2016), namely a time when a large number of new high-quality ocean carbon data were being acquired globally to assess the total anthropogenic $\mathrm{CO}_{2}$ inventory in the ocean (Sabine et al., 2004). The advantage of the Lagrangian diagnostics applied to a forward model is that it allows one to explicitly identify and quantify the flux of the transient anthropogenic component of DIC $\left(C_{\mathrm{ant}}\right)$, its trajectories (pathways), and advection timescales. The horizontal resolution of the model is nominally $2^{\circ}$ in longitude, with the latitudinal resolution varying from $0.5^{\circ}$ at the equator to a maximum of $1.9^{\circ}$, with 31 levels vertically. Details of model runs and Lagrangian diagnostics are described elsewhere (Toyama et al., 2017).

\section{Results}

In the Warm Pool of the western tropical Pacific, surface water is in near-equilibrium with respect to the $\mathrm{CO}_{2}$ in the atmosphere, i.e., $p \mathrm{CO}_{2} \mathrm{Sw}$ is generally comparable to $p \mathrm{CO}_{2}$ air (Figure $1 \mathrm{~b}$ ). This is consistent with what has been reported in previous studies (e.g., Inoue and Sugimura, 1992, Ishii and Inoue, 1995, Takahashi et al., 2009). A moderate range of spatial variability (a few tens of $\mu$ atm) is seen for $p \mathrm{CO}_{2} \mathrm{SW}$ and can be attributed to the thermodynamic effect of the variability in temperature and salinity as well as local reductions of DIC associated possibly with nitrogen fixation (Ishii et al., 2009) 
(Supplementary Figure 1). Nevertheless, an upward trend in $p \mathrm{CO}_{2} \mathrm{sw}$ is evident $\left(+1.37 \pm 0.09 \mu \mathrm{atm} \mathrm{yr}^{-}\right.$

${ }^{1}$ ) over the past three decades of 1985-2016, reflecting the presence of the anthropogenic transient in

$\mathrm{CO}_{2}$ throughout this region. However, its mean rate of increase is significantly lower than that of $p \mathrm{CO}_{2}$ air for the same period $\left(+1.74 \pm 0.02 \mu \mathrm{atm} \mathrm{yr}^{-1}\right)$.

The trend toward increasing $p \mathrm{CO}_{2} \mathrm{SW}$ in the Warm Pool is chemically attributable to the increase of sDIC $\left(+0.81 \pm 0.06 \mu \mathrm{mol} \mathrm{kg}^{-1} \mathrm{yr}^{-1}\right)$ (Figure 1d). The increase of sDIC also accounts for a lowering of $\mathrm{pH}\left(-0.0013 \pm 0.0001 \mathrm{yr}^{-1}\right)$ (Figure 1e) that indicates that the concentration of hydrogen ions has increased on average by $10 \%$ in parallel with an $11 \%$ increase in $p \mathrm{CO}_{2} \mathrm{SW}$ since 1985 . The western tropical Pacific Warm Pool is known to be the region with the highest saturation levels of carbonate minerals (Feely et al., 2009; Jing et al., 2015), providing favorable conditions for calcifying organisms such as corals. However, their saturation levels are also declining with the lowering of $\mathrm{pH} ; \Omega_{\text {cal }}$ and $\Omega_{\text {ara }}$ have decreased at a mean rate of $-0.0125 \pm 0.0010 \mathrm{yr}^{-1}$ and $-0.0083 \pm 0.0007 \mathrm{yr}^{-1}$, respectively, reflecting ocean acidification in this region (Figures $1 \mathrm{f}$ and $1 \mathrm{~g}$ ). Nevertheless, their rates of changes are, on the average, $\sim 20 \%$ slower than what would be expected if $p \mathrm{CO}_{2} \mathrm{Sw}$ were to simply follow the rate of $p \mathrm{CO}_{2}$ air increase over the same period. The slower rate of acidification identified here in this study contrasts well with the rates determined in the subtropics that are faster and consistent with those expected from the growth rate of $p \mathrm{CO}_{2}$ air within the uncertainty of analysis (e.g., Midorikawa et al., 2010; González-Dávila et al., 2010; Bates et al., 2014; Ono et al., 2019). Similar trends of slower oceanic $\mathrm{CO}_{2}$ increase in the western tropical Pacific have been reported based on the earlier version of SOCAT and an algorithm of TA from salinity and temperature (Lauvset et al., 2015) and based on the time-series measurements of inorganic carbon variables at $137^{\circ} \mathrm{E}$ section (Ono et al., 2019). The slower oceanic $\mathrm{CO}_{2}$ increase here has also been projected by Earth System Model simulations used to project the anthropogenically forced trends in the climate system (Replandy et al., 2013; Schlunegger et al., 2019).

\section{Discussion}


The observational constraint that the rate of $p \mathrm{CO}_{2} \mathrm{Sw}$ increase in the western tropical Pacific Warm Pool is not merely tracking the rate of $p \mathrm{CO}_{2}$ air increase and is slower than in the subtropics raises the question as to what oceanographic processes modulate the $p \mathrm{CO}_{2} \mathrm{sw}$ increase in this region. In the following subsections, we argue, among the array of processes controlling the rate of sDIC increase, the dominant factor controlling the rate of $p \mathrm{CO}_{2} \mathrm{sw}, \mathrm{pH}, \Omega_{\text {calc }}$ and $\Omega_{\text {arag }}$, in the Warm Pool taking the anthropogenic $\mathrm{CO}_{2}$ transport through the ocean circulation into account and using diagnostics of an ocean modeling and a constraint from inorganic carbon measurements in the ocean interior.

\subsection{Transport of Anthropogenic $\mathrm{CO}_{2}$ in and around the Tropical Pacific}

First, we hypothesize that the renewal time for Warm Pool water is not long enough to reach local air-sea equilibration of $\mathrm{CO}_{2}$. To test this hypothesis, we considered output from a global ocean circulation model ORCA2-LIM (Iudicone et al., 2016), and defined the $28^{\circ} \mathrm{C}$ isotherm as constituting

the boundary of Warm Pool waters. Invoking a suite of diagnostics previously applied to identify exchanges across the base of the surface mixed layer (Blanke et al., 2002; Toyama et al., 2017), the exchange rate is estimated across the surface bounded below and to the east by the $28^{\circ} \mathrm{C}$ isotherm and to the north and south by sections at $8.7^{\circ} \mathrm{N}$ and $8.7^{\circ} \mathrm{S}$, respectively (Figure $2 \mathrm{a}$ ). The mean annual net volume transport across the boundaries of this domain is estimated to be $113 \mathrm{~Sv}\left(10^{6} \mathrm{~m}^{3} \mathrm{~s}^{-1}\right)$, of which a significant fraction is identified at its eastern boundary through the westward South Equatorial Current (SEC) (Figure 2a). The volume of the Warm Pool defined here is $1.28 \cdot 10^{15} \mathrm{~m}^{3}$. The renewal time (volume divided by boundary fluxes) of the Warm Pool volume is thus 131 days, with this being significantly shorter than the air-sea $\mathrm{CO}_{2}$ equilibration timescale of one year in this region (Ishii et al., 2009), indicating that nonlocal ocean dynamical processes can modulate DIC trends and thereby $p \mathrm{CO}_{2} \mathrm{sw}$ in the Warm Pool.

We next analyze the annual budgets in anthropogenic $\mathrm{CO}_{2}$ for the simulated year 1995 using output from an ocean carbon cycle model (PISCES) run offline using dynamical state variables saved from the ocean circulation model ORCA2-LIM. Here our analysis includes the fluxes across the air-sea 
interface, increases in layer inventories as well as the diapycnal and horizontal transports integrated zonally over the tropical Pacific. The budgets are analyzed in six discrete layers spanning the surface down through the pycnocline (Figure 3 ). This encompasses the EUC, and extends from Warm Pool $\left(\sigma_{\theta}\right.$ $<21.9 \mathrm{~kg} \mathrm{~m}^{-3}$ ) down to the $\sigma_{\theta}=26.6 \mathrm{~kg} \mathrm{~m}^{-3}$ horizon (depths down to approximately $300 \mathrm{~m}$ ) in the equatorial band spanning $5^{\circ} \mathrm{S}-5^{\circ} \mathrm{N}$, as well in the same density layers in adjacent bands spanning $15^{\circ} \mathrm{S}-$ $5^{\circ} \mathrm{S}$ and $5^{\circ} \mathrm{N}-15^{\circ} \mathrm{N}$. These layers have been chosen so as to encompass the critical vertical scales of the shallow Subtroipcal Cell overturning. The budget analysis reveals the equatorward convergent transport of anthropogenic $\mathrm{CO}_{2}$ in the pycnocline from both hemispheres, and subsequent upward diapycnal transport within the equatorial band and divergence in the surface layers including the Warm Pool. The net annual upward diapycnal transport of anthropogenic $\mathrm{CO}_{2}$ from the upper pycnocline to the surface

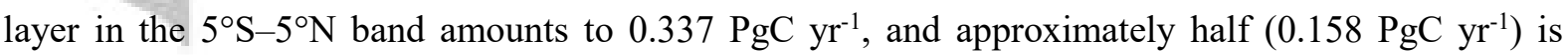
transported through the South Equatorial Current (Figure 1a) to the Warm Pool in the surface with associated buoyancy gain by heating and fresh water inputs. The interior exchanges of anthropogenic $\mathrm{CO}_{2}$ sustained through transports are three to six times larger than the net annual air-to-sea flux of anthropogenic $\mathrm{CO}_{2}$ from the atmosphere $\left(0.057 \mathrm{PgC} \mathrm{yr}^{-1}\right)$ over the same equatorial band. This reveals the predominant role of the upward cross-isopycnal anthropogenic $\mathrm{CO}_{2}$ transport from the pycnocline for acidification of the surface waters of the equatorial Pacific including the Warm Pool region. Overall, the results are consistent with those considered for the cold tongue region by Zhai et al. (2017).

For our third suite of analyses focused on attribution, we have invoked "quantitative mode" functionality in the Ariane Lagrangian diagnostics, where one begins by identifying ocean interior surfaces as starting and stopping regions for large numbers of Lagrangian particles. Importantly, by releasing particles in proportion to the physical transport across an initial section, one can then map the strength of the transports across the final section with a direct mapping to the transports across the original section. In reverse Lagrangian diagnostics (Blanke and Grima, 2011) with the same ocean circulation model (ORCA2-LIM) we identify the pathways by which nonlocal transport of anthropogenic $\mathrm{CO}_{2}$ impacts the rate of $p \mathrm{CO}_{2} \mathrm{sw}$ increase and acidification over the Warm Pool in more 
detail.

Lagrangian particles were seeded over the $28^{\circ} \mathrm{C}$ isotherm bounding the same Warm Pool domain considered for renewal time (Figure 2a). For the case where transport in the forward model was directed into the Warm Pool, they were then traced backward in time. In the first set of diagnostics, the Lagrangian particles were then stopped when they passed westward across $165^{\circ} \mathrm{E}$ or reached either the $8.7^{\circ} \mathrm{N}$ section or the $8.7^{\circ} \mathrm{S}$ section. This analysis revealed that $50 \mathrm{~Sv}(44 \%)$ of the net transport into the Warm Pool crossed $165^{\circ}$ E section within the EUC below the Warm Pool (Figure 2b), with subsequent near-surface and surface entrainment into the westward-flowing SEC and concurrent gain of buoyancy. For this pathway, nearly $73 \%$ of the waters take less than 3 years between crossing $165^{\circ} \mathrm{E}$ section within the EUC and entering the Warm Pool. The remaining $63 \mathrm{~Sv}(56 \%)$ of the transport of the flux into the Warm Pool arrives directly through equatorward pycnocline convergence with subsequent near-surface and surface entrainment into the SEC or through the low latitude western boundary currents of both hemispheres such as Mindanao Current and New Guinea Coastal Current (Fine et al., 1994) without passing through the EUC at $165^{\circ} \mathrm{E}$ (Figure 2c, d). Among the $63 \mathrm{~Sv}, 36 \mathrm{~Sv}$ is transported from the northern hemisphere across the $8.7^{\circ} \mathrm{N}$ section (Figure 2c) and the other $27 \mathrm{~Sv}$ is transported from the southern hemisphere across the $8.7^{\circ} \mathrm{S}$ section (Figure $2 \mathrm{~d}$ ).

In the second run of the Lagrangian diagnostics, the Lagrangian particles that crossed the $165^{\circ} \mathrm{E}$ section within the EUC were then re-released at their stopping points from the first step of the Lagrangian calculations along $165^{\circ} \mathrm{E}$ in order to identify their subduction source regions, i.e., their first points of intersection with the mixed layer in both hemispheres (Figure 4a). There, we identify the EUC waters as having three main sources: (i) Eastern Subtropical Mode Water (Hanawa and Talley, 2001) in the South Pacific with formation density of $24.8-25.6 \mathrm{~kg} \mathrm{~m}^{-3}$ formed on the eastern periphery of the subtropical gyre, (ii) Western and Eastern Subtropical Mode Waters in the North Pacific with formation density of $24.8-25.4 \mathrm{~kg} \mathrm{~m}^{-3}$ formed on the northern and eastern periphery of the subtropical gyre, and (iii) Subantarctic Mode Water and Antarctic Intermediate Water with formation densities of 26.8-27.2 $\mathrm{kg} \mathrm{m}^{-3}$. The range of transit times for particles from these subduction regions to reach the EUC at $165^{\circ} \mathrm{E}$ 
is broad, with $83 \%$ taking more than 5 years and a median of 8.7 years. Nevertheless, they transported a total of $0.74 \mathrm{PgC} \mathrm{yr}^{-1}$ of anthropogenic $\mathrm{CO}_{2}$ to the Warm Pool in 1995.

The origins of the Warm Pool water that does not pass through the EUC at $165^{\circ} \mathrm{E}$ is also broadly

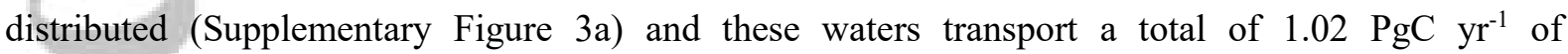
anthropogenic $\mathrm{CO}_{2}$. However, the transit time to reach the $8.7^{\circ} \mathrm{S}$ or $8.7^{\circ} \mathrm{N}$ sections tends to be shorter, with $68 \%$ of these waters taking less than 5 years. Overall, $47 \%$ of the source waters take more than 5 years to reach the EUC at $165^{\circ} \mathrm{E}$ or the sections at $8.7^{\circ} \mathrm{N} / \mathrm{S}$. The pathway of anthropogenic $\mathrm{CO}_{2}$ transport to the Warm Pool entails inter-gyre exchange of thermocline waters associated with subtropical overturning structures (Rodgers et al., 2004; Nakano et al., 2015) which generally take a decade or more.

This is consistent with ventilation ages of 5 to 20 years in the tropical Pacific thermocline inferred from the measurements of dissolved chlorofluorocarbons (Fine et al., 2001).

\subsection{Trend of DIC Increase in the EUC}

As our analysis reveals that the EUC is a principal conduit sustaining acidification of the Warm Pool, we are motivated to consider observational constraints on the EUC waters themselves dating back to the early 1990s. The analysis thus encompasses an era when high quality data of DIC and TA are available due to improved measurement technique using coulometry for DIC (Johnson et al., 1985) and data quality control using Certified Reference Material for DIC and TA measurements (Dickson, 2010) as well as a secondary data quality control by the method of crossover analyses of vertical profiles from different cruises (Tanhua et al., 2010; Olsen et al., 2019) facilitating reliable identification of decadal trends.

It is found that the increase of $\mathrm{DIC}^{\mathrm{m}}-\Delta C_{\text {org }}$ in equation (1) is evident and accounts predominantly for the increase in $\mathrm{sDIC}^{\circ}$ in the upper layers of the western tropical Pacific (Figure 5, Table 1). In contrast, the changes in $\Delta C_{\text {carb }}$ are minimal and insignificant. In the pycnocline, the linear rate of sDIC ${ }^{\text {oref }}$ change for the years 1992-2016 ranged between $+0.52 \pm 0.09 \mu \mathrm{mol} \mathrm{kg}^{-1} \mathrm{yr}^{-1}$ in LTW and $+0.72 \pm 0.10$ $\mu \mathrm{mol} \mathrm{kg}^{-1} \mathrm{yr}^{-1}$ in CTW (Table 1). These estimates of $\mathrm{sDIC}^{\mathrm{o}}$ change are not sensitive to the stoichiometric 
$\Delta \mathrm{N} / \Delta \mathrm{C}_{\text {org }} /-\Delta \mathrm{O}_{2}$ ratio we use (Table S2). Below the pycnocline where AOU is larger and more variable than in the pycnocline, the estimates of $\mathrm{sDIC}^{\mathrm{o}}$ change are more sensitive to the choice of $\Delta \mathrm{N} / \Delta \mathrm{C}_{\text {org }} /-$

$\Delta \mathrm{O}_{2}$ ratio. However, it is evident that the mean rate of sDIC change is lower in deeper layers. These results indicate the increasing transport of anthropogenic $\mathrm{CO}_{2}$ being accumulated non-locally through the EUC. The rates of $\mathrm{sDIC}^{\circ}$ increase in the EUC are comparable or slightly lower than the mean rate of sDIC increase in the overlying waters of the Warm Pool over the same period, namely since the early $1990 \mathrm{~s}\left(+0.77 \pm 0.08 \mu \mathrm{mol} \mathrm{kg} \mathrm{kr}^{-1}\right)$. This is consistent with our inference from the model diagnostics described in the previous section that the acidification of the Warm Pool is primarily supported by intergyre transport of anthropogenic $\mathrm{CO}_{2}$ within the thermocline through the EUC, with the predominant anthropogenic $\mathrm{CO}_{2}$ content of these waters crossing the air-sea interface in the subtropics.

\subsection{Attribution of slower ocean acidification in the Warm Pool}

To better constrain how ocean acidification in the western tropical Pacific may evolve in the future, it is important to identify mechanistically why the mean rate of $p \mathrm{CO}_{2} \mathrm{Sw}$ increase in this region has been slower than that of $p \mathrm{CO}_{2}$ air. As was emphasized in the previous section, one candidate process involves the time lag associated with inter-gyre exchange of thermocline waters. The $\mathrm{CO}_{2}$ increase in the atmosphere accelerated at a mean rate of $+0.26 \pm 0.05 \mathrm{ppm}^{\text {decade }}{ }^{-2}$ over 1959-2010 (Ballantyne et al., 2012) or $+0.29 \pm 0.07 \mathrm{ppm}$ decade $^{-2}$ over $1985-2015$ (WMO, 2017) on average due to increasing anthropogenic $\mathrm{CO}_{2}$ emissions. An interior residence time of order one decade during the transport from the extra-tropics to the EUC means that atmospheric $\mathrm{CO}_{2}$ increased subsequent to the water parcel losing contact with the atmosphere in the extra-tropics before re-entering through re-emergence into the surface layer of the tropics. Consequently, the less rapid rate of $p \mathrm{CO}_{2} \mathrm{Sw}$ increase than that of $p \mathrm{CO}_{2}$ air in the Warm Pool would reflect the memory of water parcels from a time when the atmospheric $p \mathrm{CO}_{2}$ air increase was slower. This in turn suggests that if policy changes were to lead to carbon removal from the ocean, reversing the sign of $\Delta p \mathrm{CO}_{2}$ over large scales, there would nevertheless be a delay in the response of the Warm Pool acidification state determined by the inter-gyre exchange timescale for 
equatorial thermocline waters.

Another candidate mechanism for the slower $p \mathrm{CO}_{2} \mathrm{sw}$ increases in the Warm Pool than that expected from the growth rate of $p \mathrm{CO}_{2}$ air for the same period could be associated with the change in the ocean circulation, i.e., an increase in the relative contribution of waters from Southern Hemisphere to the Warm Pool through the EUC. For a given thermocline density in the mean state, the southern source waters of the EUC are not only warmer and saltier, but also characterized by lower DIC ${ }^{o}$ (Supplementary Figure 4). Notably, salinity has been increasing over recent decades within the EUC (Figure 5c). This provides potential observational support for an increase in the relative contribution of the southern source to the EUC, and therefore a slowing of the rate of sDIC ${ }^{\circ}$ increase. The mean rate of salinity increase over time is the highest in the UTW $\left(+0.171 \pm 0.024\right.$ decade $^{-1}$ in $\sigma_{\theta}=23.0$ to $24.5 \mathrm{~kg} \mathrm{~m}^{-}$ ${ }^{3}$ ) (Supplementary Table 3). This could be accompanied by a change of $-0.31 \pm 0.14 \mu \mathrm{mol} \mathrm{kg}^{-1} \mathrm{yr}^{-1}$ of $\mathrm{DIC}^{\circ}$ which offsets the $\mathrm{DIC}^{\circ}$ increase due to anthropogenic $\mathrm{CO}_{2}$ accumulation, for the case where the increase in salinity reflects the increase in volume transport from the south. Nevertheless, there are caveats to this interpretation. First, increases in salinity observed in the EUC could be sustained by increases in the salinity of waters emanating from either hemisphere (Hosoda et al., 2009). Second, the slower $\mathrm{sDIC}^{\circ}$ increase in the EUC than that expected from the $p \mathrm{CO}_{2}$ air growth rate may in part also reflect the shoaling and warming of density layers associated with the salinity increase. Third, in the UTW where the mean rate of salinity increase was the highest, salinity dropped in 2015 to the level in the 1990 s but $\mathrm{sDIC}^{\mathrm{o}}$ continued to increase, suggesting that the changes in salinity were not tightly coupled with the changes in the relative contribution of waters from Southern Hemisphere to the EUC and thereby the changes in $\mathrm{SDIC}^{\circ}$. Better mechanistic understanding of why salinity is changing in the EUC is needed to understand how salinity changes and $\mathrm{sDIC}^{\circ}$ increases are linked there.

\section{Conclusions}

Invoking data synthesis products built upon oceanic $\mathrm{CO}_{2}$ measurements, we have identified a trend toward increasing surface ocean $\mathrm{CO}_{2}$ and an associated acidification in the tropical Pacific Warm 
Pool, revealing $+1.37 \pm 0.09 \mu \mathrm{atm} \mathrm{yr}^{-1}$ for $p \mathrm{CO}_{2} \mathrm{sw},+0.81 \pm 0.06 \mu \mathrm{mol} \mathrm{kg}^{-1} \mathrm{yr}^{-1}$ for sDIC, $-0.0013 \pm 0.0001$ $\mathrm{yr}^{-1}$ for $\mathrm{pH}$ and $-0.0083 \pm 0.0007 \mathrm{yr}^{-1}$ for $\Omega_{\text {ara }}$ for the years $1985-2016$. For this critically important biodiversity hot-spot region, this translates to an acidification rate that is on average $\sim 20 \%$ lower than what would be expected if the surface ocean were to simply follow the growth rate of $\mathrm{CO}_{2}$ in the overlaying atmosphere $\left(+1.74 \pm 0.02 \mu \mathrm{atm} \mathrm{yr}^{-1}\right)$. Through the combined use of observations and modeling tools (with a joint Eulerian/Lagrangian analysis), our results implicate the importance of anthropogenic $\mathrm{CO}_{2}$ transport through the Subtropical Cells and the Equatorial Undercurrent in sustaining and regulating the rate of acidification in Warm Pool surface waters.

Taken together our model attribution exercise reveals that "ocean acidification from below" is a framework that applies not only to the Warm Pool but also more generally over the equatorial band via the equatorial divergence zone to the east. Specifically it implies a key role of ocean circulation as well as the growth rate of the mixing ratio of $\mathrm{CO}_{2}$ in the atmosphere in modulating the rate of ocean acidification. Our mechanistic attribution also provides insight into the more general circulation structures and pathways sustaining acidification in future climate projections with Earth System Models (Resplandy et al., 2013). Nevertheless, the importance of ocean acidification from below should not be assumed to be limited to the equatorial Pacific. Its importance has been suggested for the acidification on the continental shelf along the west coast of North America (Feely et al. 2008, Hauri et al., 2013, Harris et al., 2013). Furthermore, using the same cyclostationary ocean carbon cycle model configuration applied here, the study of Toyama et al. (2017) highlighted a number of regions over the global ocean domain, including western boundary current regions where re-emergence rates of anthropogenic $\mathrm{CO}_{2}$ into the surface mixed layer from the thermocline are larger than local air-sea $\mathrm{CO}_{2}$ fluxes. Among the regions highlighted by Toyama et al. (2017), the western tropical Pacific Warm Pool is special in that it exhibits a higher signal-to-noise ratio for the trend in acidification rate due to the relatively weak seasonal and interannual variability there in the inorganic carbon variables. The weak seasonal and interannual variability there is interpreted to be due to the effect of cumulative DIC removal through biological production driving nitrate-depletion. Biological removal of DIC due to 
nitrate-depletion operates as a low-pass filter for DIC with this magnitude being modulated in response to the change in the strength of upwelling of pycnocline waters, and renders the trend of acidification being affected by the 'aged' waters from below emergent in the Warm Pool much earlier than in the cold tongue region. Although a number of technical and resource challenges exist for applying the methods developed here to evaluate full transient cases with high resolution models, the insights afforded with the analysis methods presented here demonstrate their value for broader applications pertaining to resource management and climate questions.

\section{Acknowledgments}

This work was not possible without the efforts of many officers, crew, scientists and technicians aboard the cruises for research and the Ship of Opportunity who acquired the high-quality oceanographic data. We are also grateful to Dr. Burke Hales and an anonymous reviewer for their insightful suggestions. The data of ocean carbon measurements we used in this work are freely accessible through the websites of JMA (http://www.data.jma.go.jp/gmd/kaiyou/db/vessel_obs/data-report/html/ship/ship_e.php),

(https://www.socat.info/index.php/data-access/),

PACIFICA (https://www.nodc.noaa.gov/ocads/oceans/PACIFICA/) and GLODAP (https://www.nodc.noaa.gov/ocads/oceans/GLODAPv2_2019/). The ocean circulation model ORCA2LIM and the ocean carbon cycle model PISCES are the components of a framework of ocean-related engines "The Nucleus for European Modelling of the Ocean (NEMO)" (https://www.nemoocean.eu/framework/components/engines/). The Ariane Lagrangian diagnostic tool is available at http://stockage.univ-brest.fr/ grima/Ariane/. Processed data sets and modeling outputs including timeseries data of inorganic carbon variables in surface seawater and partial pressure of $\mathrm{CO}_{2}$ in the atmosphere in the Warm Pool region presented in Figure 1, data of vertical profiles of respirationcorrected sDIC and sTA in the western Pacific equatorial zone shown in Figure S2, time-series data of respiration-corrected sDIC on reference potential density in the Equatorial Undercurrent shown in 
Figure 5 and those of respiration-corrected sTA and preformed sTA, and outputs of PISCES run using circulation fields from a cyclostationary normal-year-forced ORCA2-LIM run, and the results of its diagnostics as shown in Figures 2, 4 and S3, are available through http://dogfish.princeton.edu/ACIDIFICATION_BELOW/. M.I., K.T., D.S., N.K., H.O., K.E. and T.N. thank support from Meteorological Research Institute's research fund C4 for the study of ocean biogeochemistry and acidification and MEXT KAKENHI grant JP15H05818 (NEOPS), 16H01594 (OMIX), and 19H05700 (HotSpot). Support for K.B.R. came through the Institute for Basic Science project code IBS-R028-D1. This is contribution 4901 from the Pacific Marine Environmental Laboratory of NOAA. Ocean $\mathrm{CO}_{2}$ data synthesis team of PACIFICA supported by PICES and those of SOCAT and GLODAPv2 supported by many programs and organizations under the auspices of IOCCP, SOLAS and IMBeR are also acknowledged.

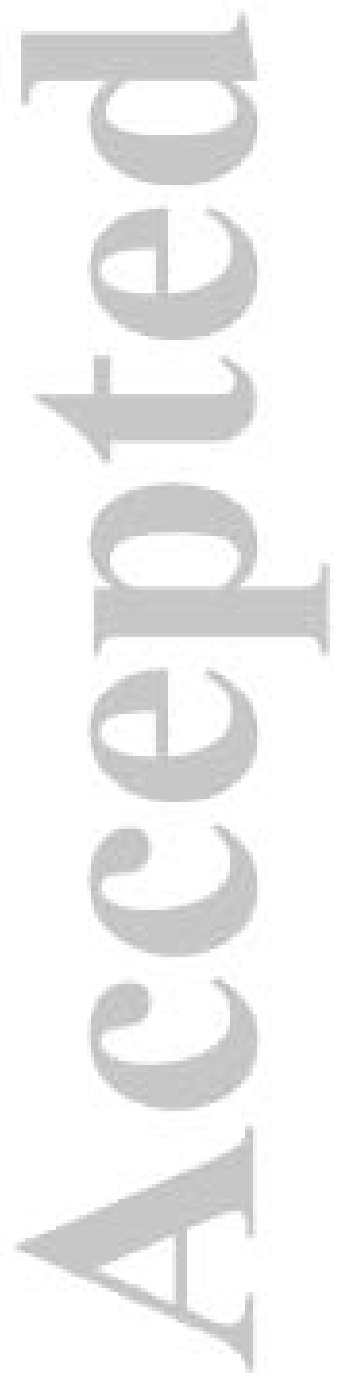




\section{References}

Akima, H. (1991), A method of univariate interpolation that has the accuracy of a third-degree polynomial, ACM Transactions on Mathematical Software, 17, 341-366, doi:10.1145/114697.116810.

Albright, R., Y. Takeshita, D. A. Koweek, A. Ninokawa, K. Wolfe, T. Rivlin, Y. Nebuchina, J. Young, and K. Caldeira, (2018), Carbon dioxide addition to coral reef waters suppresses net community calcification, Nature, 555, 516-519, doi:10.1038/nature25968.

Anderson, L. A., and J. L. Sarmiento (1994), Redfield ratios of remineralization determined by nutrient data analysis. Global Biogeochemical Cycles, 8, 65-80, doi:10.1029/93GB03318.

Bakker, D. C. E., B. Pfeil, C. S. Landa, N. Metzl, K. M. O'Brien, A. Olsen et al. (2016), A multidecade record of high quality $\mathrm{fCO}_{2}$ data in version 3 of the Surface Ocean $\mathrm{CO}_{2}$ Atlas (SOCAT), Earth System Science Data, 8, 383-413, https://doi.org/10.5194/essd-8-383-2016.

Ballantyne, A. P., C. B. Alden, J. B. Miller, P. P. Tans, and J. W. C. White (2012), Increase in observed net carbon dioxide uptake by land and oceans during the past 50 years, Nature, 488, 70-73, doi:10.1038/nature11299.

Bates, N. R., Y. M. Astor, M. J. Church, K. Currie, J. E. Dore, M. Gonzalez-Davila et al. (2014), A time-series view of changing ocean chemistry due to ocean uptake of anthropogenic $\mathrm{CO}_{2}$ and ocean acidification, Oceanography, 27, 126-141, http://dx.doi.org/10.5670/oceanog.2014.16.

Blanke, B., S. Speich, G. Madec, and R. Mauge (2002), A global diagnostic of interior ocean ventilation, Geophysical Research Letters, 29, doi:10.1029/2001GL013727.

Blanke, B., and N. Grima (2011), ARIANE v2.2.6, CNRS/IUEM/Université de Bretagne Occidentale/IRD/Ifremer/Laboratoire de Physique des Océans. Retrieved from http://stockage.univ-brest.fr/ grima/Ariane/

Burke, L., K. Reytar, M. Spalding, and A. Perry (2011), Reefs at risk revisited. Washington D. C.: World Resources Institute, https://www.wri.org/publication/reefs-risk-revisited.

Burke, L., K. Reytar, M. Spalding, and A. Perry (2012), Reefs at risk revisited in the coral triangle, Washington D. C., World Resources Institute, http://www.wri.org/publication/reefs-riskrevisited-coral-triangle.

Deutsch, C., N. Gruber, R. M. Key, J. L. Sarmiento, and A. Ganachaud (2001), Denitrification and N2 fixation in the Pacific Ocean, Global Biogeochem. Cycles, 15, 483- 506, doi:10.1029/2000GB001291.

Dickson, A.G., and J. P. Riley, (1979), The estimation of acid dissociation constants in seawater media from potentiometric titrations with strong base. I. The ionic product of water $\left(K_{\mathrm{W}}\right)$. Marine Chemistry, 7, 89-99. https://doi.org/10.1016/0304-4203(79)90001-X

Dickson, A. G. (1990), Standard potential of the reaction: $\mathrm{AgCl}(\mathrm{s})+1 / 2 \mathrm{H}_{2}(\mathrm{~g})=\mathrm{Ag}(\mathrm{s})+\mathrm{HCl}(\mathrm{aq})$, and the standard acidity constant of the ion $\mathrm{HSO}_{4}^{-}$in synthetic sea water from 273.15 to $318.15 \mathrm{~K}$, Journal of Chemical Thermodynamics, 22, 113-127, https://doi.org/10.1016/0021$\underline{9614(90) 90074-Z}$ 
Dickson, A. G., C. L. Sabine, and J. R. Christian (Eds.) (2007), Guide to best practices for ocean $\mathrm{CO}_{2}$ measurements. PICES Special Publication 3, 191 pp.

Dickson, A. G. (2010), Standards for ocean measurements, Oceanography, 23, 34-47, https://doi.org/10.5670/oceanog.2010.22.

Feely, R. A., R. Wanninkhof, H. B. Milburn, C. E. Cosca, M. Stapp, and P. P. Murphy (1998), A new automated underway system for making high precision $\mathrm{pCO}_{2}$ measurements onboard research ships, Analytical Chimica Acta, 377, 185-191, https://doi.org/10.1016/S00032670(98)00388-2

Feely, R. A., Wanninkhof, R., Takahashi, T., \& Tans, P. (1999). Influence of E1 Niño on the equatorial Pacific contribution to atmospheric $\mathrm{CO}_{2}$ accumulation. Nature, 398, 597-601. doi: $10.1038 / 19273$

Feely, R. A., T. Takahashi, T., R. Wanninkhof, M. J. McPhaden, C. E. Cosca, S. C. Sutherland, and M. E. Carr (2006), Decadal variability of the air-sea $\mathrm{CO}_{2}$ fluxes in the equatorial Pacific Ocean, Journal of Geophysical Research: Oceans, 111, C08S90, doi:10.1029/2005JC003129.

Feely, R. A., C. L. Sabine, J. M. Hernandez-Ayon, D. Ianson, D., and B. Hales (2008), Evidence for upwelling of corrosive "acidified" water onto the continental shelf. Science, 320(5882), 14901492, doi:10.1126/ science.1155676.

Feely, R. A., S. C. Doney, and S. R. Cooley (2009), Ocean acidification: Present conditions and future changes in a high- $\mathrm{CO}_{2}$ world. Oceanography, 22, 36-47, https://doi.org/10.5670/oceanog.2009.95.

Fine, R. A., R. Lukas, F. M. Bingham, M. J. Warner, and R. H. Gammon (1994), The western equatorial Pacific: A water mass crossroads. Journal of Geophysical Research: Oceans, 99, 25063-25080, doi:10.1029/94JC02277.

Fine, R. A., K. A. Maillet, K. F. Sullivan, and D. Willey (2001), Journal of Geophysical Research: Oceans, 106, 22159-22178, doi:10.1029/1999JC000184.

García, H. E. and L. I. Gordon (1992), Oxygen solubility in seawater: Better fitting equations, Limnology and Oceanography, 37, 1307-1312, doi:10.4319/1o.1992.37.6.1307.

Gattuso, J. -P., A. Magnan, R. Billé, W. W. L. Cheung, E. L.Howes, F. Joos, et al. (2015), Contrasting futures for ocean and society from different anthropogenic $\mathrm{CO}_{2}$ emissions scenarios, Science, 349(6243), aac4722, doi:10.1126/science.aac4722.

Gonzalez-Davila, M., J. M. Santana-Casiano, M. J. Rueda, and O. Llinas (2010), The water column distribution of carbonate system variables at the ESTOC site from 1995 to 2004, Biogeosciences, 7, 3067-3081, http://dx.doi.org/10.5194/bg-7-3067-2010.

Gruber, N., J. L. Sarmiento, and T. F. Stocker (1996), An improved method for detecting anthropogenic $\mathrm{CO}_{2}$ in the oceans, Global Biogeochemical Cycles, 10, 809-837, https://doi.org/10.1029/96GB01608.

Hanawa, K., and L.Talley (2001), Mode Waters, In G. Siedler, J. Church, J., J. Gould (Eds.), Ocean Circulation and Climate, International Geophysics Series (Vol. 77, pp. 373-386), San Diego, 
CA: Academic.

Harris, K. E., M. D. DeGrandpre, and B. Hales (2013), Aragonite saturation states in a coastal upwelling zone, Geophysical Research Letters, 40, 2720-2725, doi: 10.1002/grl.50460.

Hauri, C., N. Gruber, M. Vogt, S. C. Doney, R. A. Feely, Z. Lachkar, A. Leinweber, A. M. P. McDonnell, M. Munnich, and G.-K. Plattner (2013), Spatiotemporal variability and long-term trends of ocean acidification in the California Current System, Biogeoscience, 10, 193-216, doi:10.5194/ bg-10-193-2013.

Hoegh-Guldberg, O., P. J. Mumby, A. J. Hooten, R. S. Steneck, P. Greenfield, E. Gomez, et al. (2007), Coral reef under rapid climate change and ocean acidification, Science, 318, 1737 1742, doi:10.1126/science.1152509.

Hosoda, S., T. Suga, N. Shikama, and K. Mizuno (2009), Global surface salinity change detected by Argo and its implication for hydrological cycle intensification, Journal of Oceanography, 65 , 579-596, doi:10.1007/s10872-009-0049-1.

Inoue, $\mathrm{H}$. Y. and Y. Sugimura (1992), Variations and distributions of $\mathrm{CO}_{2}$ in and over the equatorial Pacific during the period from the 1986/88 El Niño event to the 1988/89 La Niña event, Tellus, Series B, 44, 1-22, https://doi.org/10.3402/tellusb.v44i1.15417.

Inoue, H. Y., H. Matsueda, M. Ishii, K. Fushimi, M. Hirota, I. Asanuma, and Y. Takasugi (1995), Long-term trend of the partial pressure of carbon dioxide $\left(\mathrm{pCO}_{2}\right)$ in surface waters of the western North Pacific, 1984-1993, Tellus, Series B, 47, 391-413, https://doi.org/10.3402/tellusb.v47i4.16057.

Inoue, $\mathrm{H}$. Y. (2000), $\mathrm{CO}_{2}$ exchange between the atmosphere and the ocean: Carbon cycle studies of the Meteorological Research Institute since 1968, In N. Handa, E. Tanoue, T. Hama (Eds.), Dynamics and characterization of marine organic matter, Ocean sciences research book series (Vol.2, pp.509-531), Tokyo, Terra Scientific/Springer, doi:10.1007/978-94-017-1319-1.

Ishii, M. and H. Y. Inoue (1995), Air-sea exchange of $\mathrm{CO}_{2}$ in the central and western equatorial Pacific in 1990, Tellus, Series B, 47, 447-460, https://doi.org/10.1034/j.1600-0889.47.issue4.5.x.

Ishii, M., S. Saito, T. Tokieda, T., Kawano, K. Matsumoto, and H. Y. Inoue (2004), Variability of surface layer $\mathrm{CO}_{2}$ parameters in the western and central equatorial Pacific, In M. Shiyomi, $\mathrm{H}$. Kawahata, H. Koizumi, A. Tsuda, Y. Awaya (Eds.), Global Environmental Change in the Ocean and on Land (pp. 59-94), Tokyo, Terrupub.

Ishii, M., H. Y. Inoue, T. Midorikawa, S. Saito, T. Tokieda, D. Sasano, et al. (2009), Spatial variability and decadal trend of the oceanic $\mathrm{CO}_{2}$ in the western equatorial Pacific warm/fresh water, Deep-Sea Research, Part II, 56(8-10), 591-606, https://doi.org/10.1016/j.dsr2.2009.01.002.

Ishii, M., R. A. Feely, K. B. Rodgers, G.-H. Park, R. Wanninkhof, D. Sasano, et al. (2014), Air-sea $\mathrm{CO}_{2}$ flux in the Pacific Ocean for the period 1990-2009, Biogeosciences, 11(3), 709-734, https://doi.org/10.5194/bg-11-709-2014.

Iudicone, D., K. B. Rodgers, Y. Plancherel, O. Aumont, T. Ito, R. M. Key et al. (2016), The formation of the ocean's anthropogenic carbon reservoir, Scientific Reports, 6, 35473, 
https://doi.org/10.1038/srep35473.

Jing, L.-Q., R. A. Feely, B. R. Carter, D. J. Greeley, D. K. Gledhill, and K. M. Arzayus (2015), Climatological distribution of aragonite saturation state in the global oceans, Global Biogeochemical Cycles, 29, 1656-1673, doi:10.1002/2015GB005198.

Johnson, K. M., King, A. E., and J. McN. Sieburth (1985), Coulometric $\mathrm{TCO}_{2}$ analyses for marine studies; an introduction, Marine Chemistry, 16, 61-82, https://doi.org/10.1016/03044203(85)90028-3.

Key, R. M., A. Kozyr, C. L. Sabine, K. Lee, R. Wanninkhof, R., J. L. Bullister, et al. (2004), A global ocean carbon climatology: Results from Global Data Analysis Project (GLODAP), Global Biogeochemical Cycles, 18, GB4031, doi.org/10.1029/2004GB002247.

Kleypas, J. A., R. W. Buddemeier, D. Archer, J.-P. Gattuso, C. Langdon, and B. N. Opdyke (1999), Geochemical consequences of increased atmospheric carbon dioxide on coral reefs, Science, 284, 118-120, doi:10.1126/science.284.5411.118.

Langdon, C., W. S. Broecker, D. E. Hammond, E. Glenn, K. Fitzsimmons, S. G. Nelson (2003), Effect of elevated $\mathrm{CO}_{2}$ on the community metabolism of an experimental coral reef, Global Biogeochemical Cycles, 17, 1011, doi:10.1029/2002GB001941.

Lewis, E., and D. Wallace (1998), Program developed for $\mathrm{CO}_{2}$ system calculations, ORNL/CDIAC105, Carbon Dioxide Information Analysis Center, Oakridge National Laboratory, Oakridge.

Lueker, T. J., A. G. Dickson, and C. D. Keeling (2000), Ocean $\mathrm{pCO}_{2}$ calculated from dissolved inorganic carbon, alkalinity, and equations for $K_{1}$ and $K_{2}$ : validation based on laboratory measurements of $\mathrm{CO}_{2}$ in gas and seawater at equilibrium, Marine Chemistry, 70, 105-119, https://doi.org/10.1016/S0304-4203(00)00022-0.

Midorikawa, T., M. Ishii, S. Saito, D. Sasano, N. Kosugi, T. Motoi, et al. (2010), Decreasing pH trend estimated from 25-yr time-series of carbonate parameters in the western North Pacific, Tellus, Series B, 62(5), 649-659, doi:10.1111/j.1600-0889.2010.00474.x.

Millero, F. J., K. Lee, M. Roche (1998), Distribution of alkalinity in the surface waters of the major oceans, Marine Chemistry, 60, 111-130, https://doi.org/10.1016/S0304-4203(97)00084-4.

Mucci, A. (1983), The solubility of calcite and aragonite in seawater at various salinities, temperatures, and one atmosphere total pressure, American Journal of Science, 283, 780-799, doi:10.2475/ajs.283.7.780.

Nakano, H., M. Ishii, K. B. Rodgers, H. Tsujino, and G. Yamanaka (2015), Anthropogenic $\mathrm{CO}_{2}$ uptake, transport, storage, and dynamical controls in the ocean imposed by the meridional overturning circulation: A modeling study, Global Biogeochemical Cycles, 29, 1706-1724, doi:10.1002/2015GB005128.

Olsen, A., R. M. Key, S.van Heuven, S. K. Lauvset, A. Velo, X. Lin et al. (2016), The Global Ocean Data Analysis Project version 2 (GLODAPv2) - an internally consistent data product for the world ocean, Earth System Science Data, 8, 297-323, https://doi.org/10.5194/essd-8-297-2016.

Olsen, A., N. Lange, R. M. Key, T. Tanhua, M. Álvarez, S. Becker et al. (2019), GLODAPv2.2019- 
an update of GLODAPv2, Earth System Science Data, 11, 1437-1461,

https://doi.org/10.5194/essd-11-1437-2019.

Ono, H., N. Kosugi, K. Toyama, H. Tsujino, A. Kojima, K. Enyo, et al. (2019), Acceleration of ocean acidification in the western North Pacific. Geophysical Research Letters, 46, 13161-13169, https://doi.org/10.1029/2019GL085121.

Pandolfi, J. M., S. R. Connolly, D. J. Marshall, and A. L. Cohen (2011), Projecting coral reef futures under global warming and ocean acidification, Science, 333, 418-422, doi:10.1126/science.1204794.

Pfeil, B., A. Olsen, D. C. E. Bakker, S. Hankin, H. Koyuk, A. Kozyr, et al. (2013), A uniform, quality controlled Surface Ocean $\mathrm{CO}_{2}$ Atlas (SOCAT), Earth System Science Data, 5, 125-143, https://doi.org/10.5194/essd-5-125-2013.

Poisson, A., N. Metzl, C. Brunet, B. Schauer, B. Brés, D. Ruiz-Pino, and F. Louanchi (1993), Variability of sources and sinks of $\mathrm{CO}_{2}$ and in the western Indian and Southern Oceans during the year 1991. Journal of Geophysical Research, 98, 22759-22778, https://doi.org/10.1029/93JC02501.

Resplandy, L., L. Bopp, J. C. Orr, and J. P. Dunne (2013), Role of mode and intermediate waters in the future ocean acidification: Analysis of CMIP5 models, Geophysical Research Letters, 40, 3091-3095, doi:10.1002/grl.50414.

Roberts, C. M., C. J. McClean, J. E. N.Veron, J. P. Hawkins, G. R. Allen, D. E. McAllister et al. (2002), Marine biodiversity hotspots and conservation priorities for tropical reefs, Science, 295, 1280-1284, doi:10.1126/science.1067728.

Rodgers, K. B., B. Blanke, G. Madec, O. Aumont, P. Ciais, and J.-C. Dutay (2003), Extratropical sources of equatorial Pacific upwelling in an OGCM, Geophysical Research Letters, 30, 1084, doi:10.1029/2002GL016003.

Rodgers, K. B., O. Aumont, G. Madec, C. Menkes, B. Blanke, P. Monfray, J. C. Orr, and D. P. Schrag (2004), Radiocarbon as a thermocline proxy for the eastern equatorial Pacific Geophysical Research Letters, 31, L14314, doi:10.1029/204GL019764.

Sabine, C. L., R. M. Key, and M. Hall (1999), Carbon dioxide, hydrographic, and chemical data obtained during the R/V Thomas G. Thompson cruise in the Pacific Ocean (WOCE section P10, October 5-November 10, 1993, (ORNL/CDIAC-122, NDP-071), Oak Ridge, TN: Carbon Dioxide Information Analysis Center, Oak Ridge National Laboratory, U.S. Department of Energy, https://www.nodc.noaa.gov/ocads/oceans/ndp_071/

Sabine, C. L., R. A. Feely, R. M. Key, J. L. Bullister, F. J. Millero, K. Lee, et al. (2002), Distribution of anthropogenic $\mathrm{CO}_{2}$ in the Pacific Ocean, Global Biogeochemical Cycles, 16, 1083, doi:10.1029/2001GB001639.

Sabine, C. L., R. A. Feely, N. Gruber, R. M. Key, K. Lee, J. L. Bullister, et al. (2004), The oceanic sink for anthropogenic $\mathrm{CO}_{2}$, Science, 305(5682), 367-371, doi:10.1126/science.1097403.

Schlunegger, S., K. B. Rodgers, J. L. Sarmiento, T. L. Frölicher, J. Dunne, M. Ishii, and R. Slater 
(2019), Emergence of anthropogenic signals in the ocean carbon cycle, Nature Climate Change, 9, 719-725, doi:10.1038/s41558-019-0553-2.

Sloyan, B., G. C. Johnson, and W. S. Kessler (2003), The Pacific cold tongue: A pathway for interhemispheric exchange, Journal of Physical Oceanography, 33, 1027-1043, https://doi.org/10.1175/1520-0485(2003)033<1027:TPCTAP>2.0.CO;2.

Suzuki, T., M. Ishii, M. Aoyama, J. R.Christian, K. Enyo, T. Kawano, et al. (2013), PACIFICA data synthesis project (ORNL/CDIAC-159, NDP-092), Oak Ridge, TN: Carbon Dioxide Information Analysis Center, Oak Ridge National Laboratory, U.S. Department of Energy, doi:10.3334/CDIAC/OTG.PACIFICA_NDP092.

Takahashi, T., S. Sutherland, R. A. Feely, C. E. Cosca (2003), Decadal variation of the surface water $\mathrm{PCO}_{2}$ in the western and central equatorial Pacific, Science, 302, 852-856, doi:10.1126/science. 1088570 .

Takahashi, T., S. C. Sutherland, R. Wanninkhof, C. Sweeney, R. A. Feely, D. W. Chipman, et al. (2009), Climatological mean and decadal change in surface ocean $\mathrm{pCO}_{2}$, and net sea-air $\mathrm{CO}_{2}$ flux over the global oceans, Deep Sea Research Part II, 56, 554-577, https://doi.org/10.1016/j.dsr2.2008.12.009.

Takatani, Y., K. Enyo, Y. Iida, A. Kojima, T. Nakano, D. Sasano, et al. (2014), Relationships between total alkalinity in surface water and sea surface dynamic height in the Pacific Ocean, Journal of Geophysical Research Oceans, 119, 2806-2814, doi:10.1002/2013JC009739.

Tanhua, T., S. van Heuven, R. M. Key, A.Velo, A. Olsen, A., and C. Schirnick (2010), Quality control procedures and methods of the CARINA database, Earth System Science Data, 2, 35-49, https://doi.org/10.5194/essd-2-35-2010.

Toyama, K., K. B. Rodgers, B. Blanke, D. Iudicone, M. Ishii, O. Aumont, and J. L. Sarmiento (2017), Large reemergence of anthropogenic carbon into the ocean's surface mixed layer sustained by the ocean's overturning circulation, Journal of Climate, 30, 8615-8631, https://doi.org/10.1175/JCLI-D-16-0725.1.

Wanninkhof, R. and K. Thoning (1993), Measurement of fugacity of $\mathrm{CO}_{2}$ in surface water using continuous and discrete sampling methods, Marine Chemistry, 44, 189-205, https://doi.org/10.1016/0304-4203(93)90202-Y

Weiss, R.F. (1974), Carbon dioxide in water and seawater: the solubility of a non-ideal gas, Marine Chemistry, 2, 23-25, https://doi.org/10.1016/0304-4203(74)90015-2.

WMO (2017), WDCGG data summary, 41, https://gaw.kishou.go.jp/publications/summary.

Wong, C. S., Y.-H. Chan, J. S. Page, G. E. Smith, and R. D. Bellegay (1993), Changes in equatorial $\mathrm{CO}_{2}$ flux and new production estimated from $\mathrm{CO}_{2}$ and nutrient levels in Pacific surface waters during the 1986/87 E1 Niño, Tellus B, 45, 64-79, https://doi.org/10.3402/tellusb.v45i1.15580.

WorldFish (2019), ReefBase: A global information system for coral reefs, May 2019, Retrieved from http://www.reefbase.org/global database/.

Zhai, P., K. B. Rodgers, S. M. Griffies, R. D. Slater, D. Iudicone, J. L. Sarmiento, and L. Resplandy 
(2017), Mechanistic drivers of anthropogenic carbon in the equatorial Pacific, Geophysical Research Letters, 44, https://doi.org/10.1002/2017GL073758.

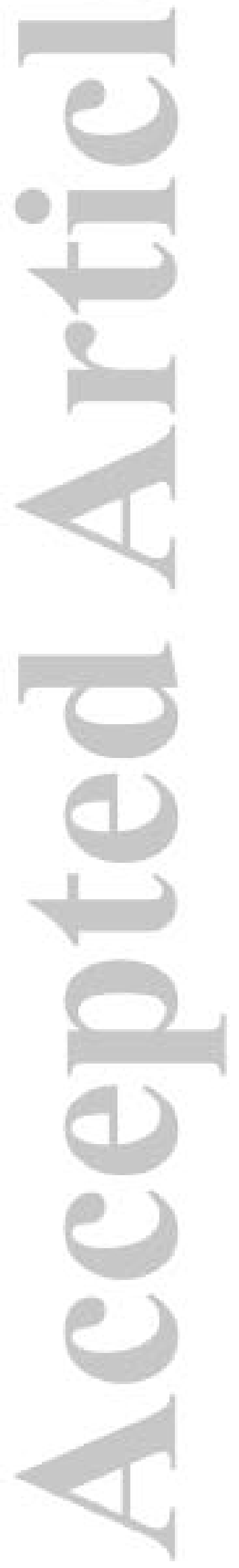


Table 1. Mean rates of change \pm standard error $\left(\mu \mathrm{mol} \mathrm{kg}^{-1} \mathrm{yr}^{-1}\right)$ in the components of salinity-normalized preformed DIC $\left(\mathrm{sDIC}^{\circ}\right)$ in the interior of the western Pacific equatorial band $\left(130^{\circ} \mathrm{E}-180^{\circ}, 1^{\circ} \mathrm{S}-1^{\circ} \mathrm{N}\right)$ for the years 1992-2016. Stoichiometric ratios of $\Delta N / \Delta C_{\text {org }} /-\Delta \mathrm{O}_{2}=1 / 16 / 117 / 170$ (Anderson and Sarmiento, 1994) were used for the calculation of sDIC ${ }^{\circ}$. UTW: Upper Thermocline Water; CTW: Central Thermocline Water; LTW: Lower Thermocline Water; TSW: Thermostad Water; MW: Mode Water; UIW: Upper Intermediate Water; LIW: Lower Intermediate Water; UDW: Upper Deep Water.

\begin{tabular}{ccccccc}
\hline Name & Density range & $\left(\mathrm{DIC}^{\mathrm{m}}-\Delta C_{\text {org }}\right)^{\text {ref }}$ & $\mathrm{n}$ & $\Delta C_{\text {carb }}{ }^{\text {ref }}$ & $\mathrm{n}$ & SDIC $^{\text {ref }}$ \\
\hline UTW & $23.0-24.5 \sigma_{\theta}$ & $+0.62 \pm 0.09^{*}$ & 50 & $+0.04 \pm 0.04$ & 23 & $+0.58 \pm 0.10$ \\
CTW & $24.5-25.5 \sigma_{\theta}$ & $+0.74 \pm 0.09^{*}$ & 40 & $+0.03 \pm 0.05$ & 20 & $+0.72 \pm 0.10$ \\
LTW & $25.5-26.3 \sigma_{\theta}$ & $+0.53 \pm 0.08^{*}$ & 51 & $+0.01 \pm 0.04$ & 23 & $+0.52 \pm 0.09$ \\
TSW & $26.3-26.6 \sigma_{\theta}$ & $+0.47 \pm 0.07^{*}$ & 44 & $+0.00 \pm 0.05$ & 23 & $+0.47 \pm 0.09$ \\
MW & $26.6-26.9 \sigma_{\theta}$ & $+0.42 \pm 0.06^{*}$ & 50 & $-0.03 \pm 0.05$ & 23 & $+0.44 \pm 0.08$ \\
UIW & $26.9-27.2 \sigma_{\theta}$ & $+0.24 \pm 0.06^{*}$ & 43 & $-0.13 \pm 0.07$ & 20 & $+0.37 \pm 0.09$ \\
LIW & $27.2-27.5 \sigma_{\theta}$ & $+0.11 \pm 0.05^{*}$ & 44 & $-0.05 \pm 0.04$ & 25 & $+0.16 \pm 0.06$ \\
UDW & $27.5-27.7 \sigma_{\theta}$ & $+0.07 \pm 0.05$ & 44 & $-0.08 \pm 0.05$ & 23 & $+0.14 \pm 0.06$ \\
\hline
\end{tabular}

* Statistically significant $(\mathrm{p}<0.05)$

${ }^{\dagger} \Delta C_{\text {carb }}{ }^{\text {ref }}=0.5 \cdot\left\{\left(\mathrm{TA}^{\mathrm{m}}+r_{\mathrm{N} / \mathrm{O} 2} \cdot \mathrm{AOU}\right)^{\mathrm{ref}}-\mathrm{TA}^{\text {oref }}\right\}$ 

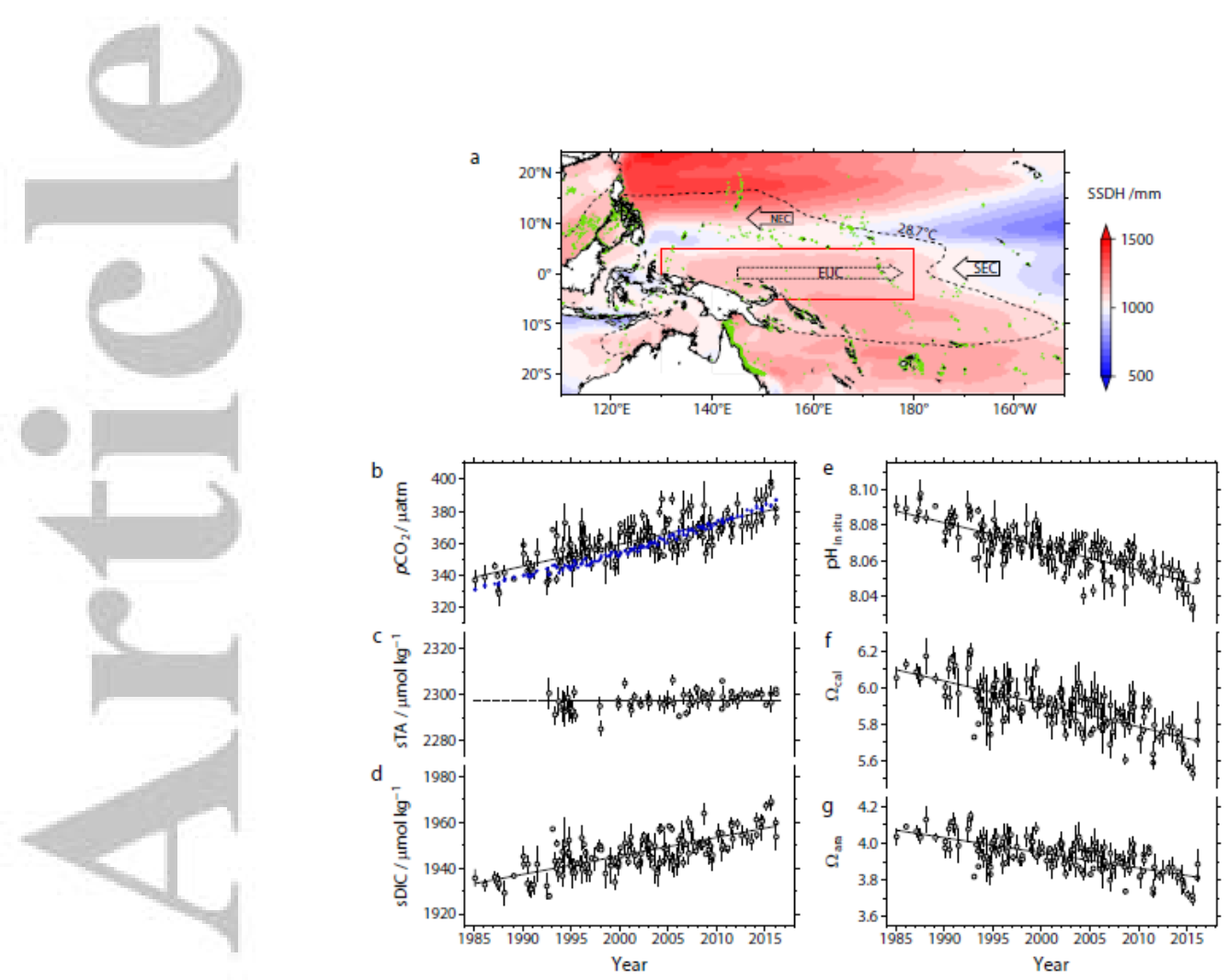

Figure 1. Multi-decadal trends toward increasing $\mathrm{CO}_{2}$ and acidification in the surface layer of the western tropical Pacific Warm Pool. (a) Schematic view of the western tropical Pacific showing the distribution of coral reefs (green plots) (WorldFish, 2019). Superposed also on the map are the mean sea surface dynamic height (SSDH) (color), the outcrops of the $28.7^{\circ} \mathrm{C}$ isotherm at the surface (broken line) for the years 2011-2015 (Japan Meteorological Agency, https://ds.data.jma.go.jp/gmd/goos/data/rrtdb/jma-pro.html), and major surface and subsurface currents including the North Equatorial Current (NEC), the South Equatorial Current (SEC), and the Equatorial Undercurrent (EUC) (double-dashed arrow). Shown with a red rectangle is the area of observational data analysis evaluated for ocean acidification in this work $\left(130^{\circ} \mathrm{E}-180^{\circ}, 5^{\circ} \mathrm{S}-5^{\circ} \mathrm{N}\right)$. Mean values (open circles) and standard deviations (vertical bars) for each month over the Warm Pool $\left(T>28.7^{\circ} \mathrm{C}\right.$ and $S<34.7$ ) and their linear trends for 1985-2016 are shown for (b) $p \mathrm{CO}_{2} \mathrm{Sw}$ (black), (c) salinity-normalized $(S=35)$ total alkalinity (sTA), (d) salinity-normalized DIC (sDIC), (e) $\mathrm{pH}$ at in situ temperature and salinity, (f) saturation indices of calcium carbonate minerals calcite $\left(\Omega_{\text {cal }}\right)$ and (g) aragonite $\left(\Omega_{\text {ara }}\right)$. Also shown in (b) are the data for $p \mathrm{CO}_{2}$ air (blue) measured during the same cruises as those of $p \mathrm{CO}_{2} \mathrm{SW}$ measurements. 


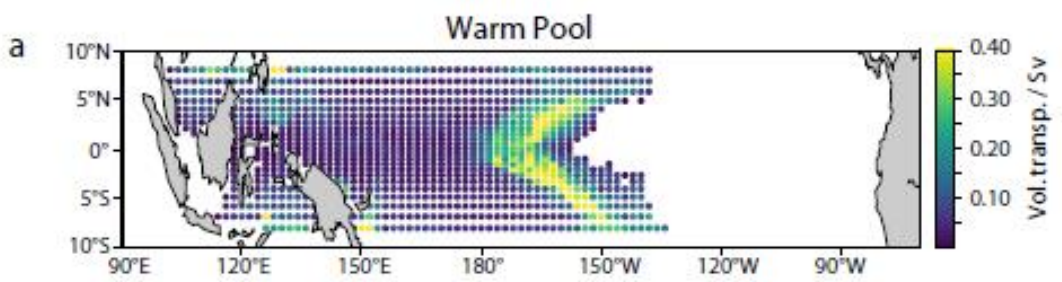

b
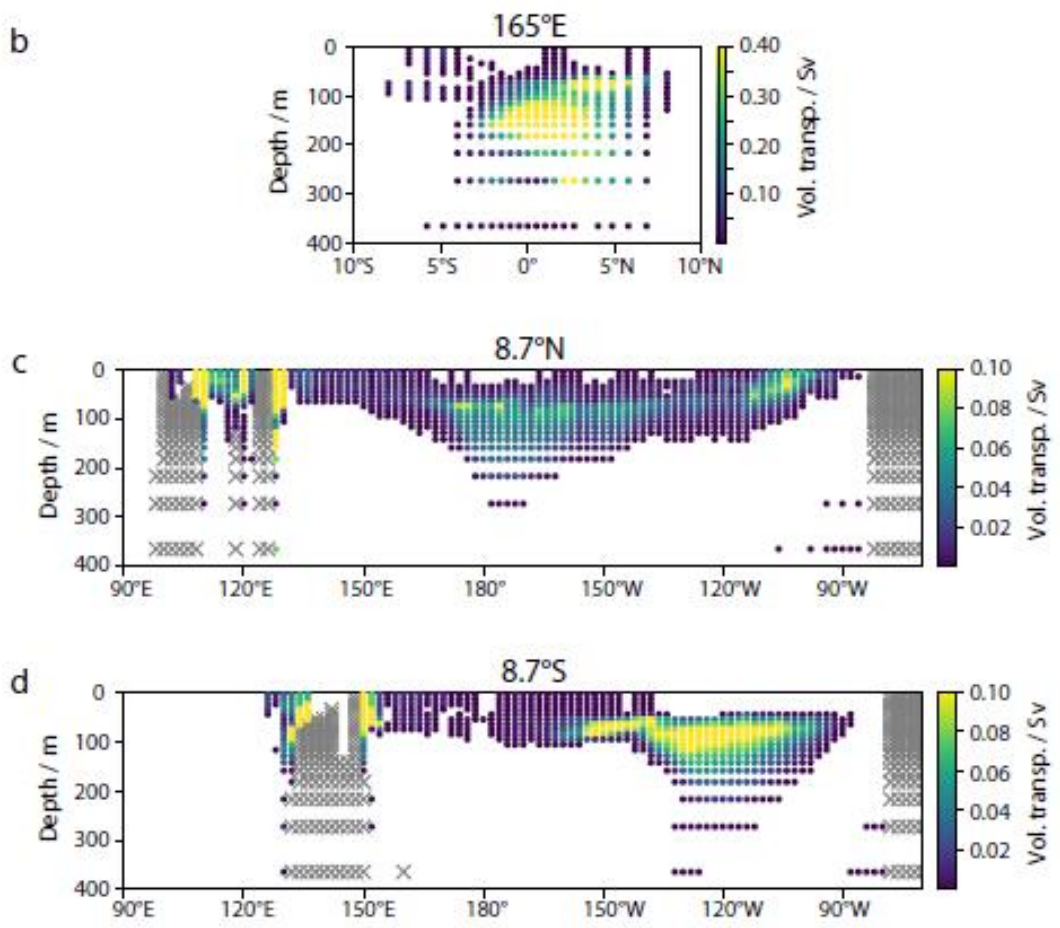

Figure 2. The rate of exchange across the volume bounded below by $28^{\circ} \mathrm{C}$ isotherm and to the north and south by the $8.7^{\circ} \mathrm{N}$ and $8.7^{\circ} \mathrm{S}$ sections, respectively. (a) Particles seeded on the boundaries and the volume transport in the control volume of the Warm Pool. (b) Distribution of the volume transport across $165^{\circ} \mathrm{E}$ section that enters the Warm Pool. (c) Distribution of the volume transport across $8.7^{\circ} \mathrm{N}$ that enters the Warm Pool but not through the EUC at $165^{\circ}$ E. (d) Same as (c) but across $8.7^{\circ} \mathrm{S}$. This experiment was done with a global ocean circulation model (Iudicone et al., 2016) to evaluate the contribution of waters feeding Warm Pool formation in the western tropical Pacific. 


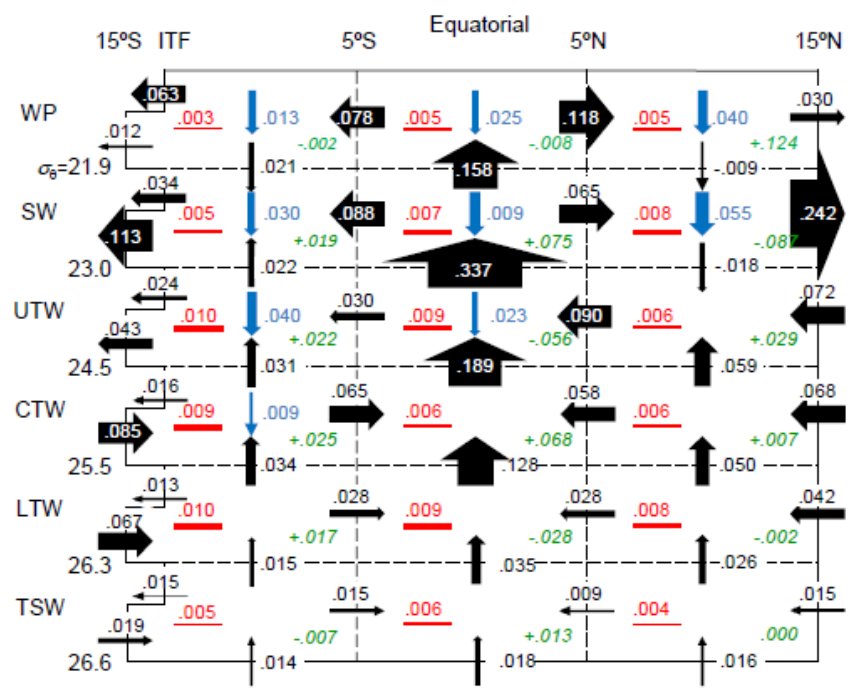

Diapycnal anth. $\mathrm{CO}_{2}$ transport
Anth. $\mathrm{CO}_{2}$ uptake from the atmosphere
$\mathrm{CO}_{2}$ inventory change

Figure 3. Annual mean exchanges of anthropogenic $\mathrm{CO}_{2}$ and layer budgets $\left(\mathrm{PgC}^{-1}{ }^{-1}\right)$ in the mid1990 s integrated zonally in a density framework over the tropical Pacific $\left(15^{\circ} \mathrm{S}-15^{\circ} \mathrm{N}\right)$. The fluxes were identified using biweekly output fields from an ocean carbon cycle model embedded on the ocean circulation model ORCA2-LIM-PISCES (Iudicone et al., 2016). ITF: Indonesian Throughflow; WP:

Warm Pool; SW: Surface Water; UTW: Upper Thermocline Water; CTW: Central Thermocline Water; LTW: Lower Thermocline Water; TSW: Thermostad Water. The figure reveals a general pattern of equatorial convergence within the pycnocline (thermocline) layers and a poleward divergence of surface and near-surface waters. Maximum upwelling defined as a cross-isopycnal transport occurs in this coarse-grained layering of the pycnocline across the $\sigma_{\theta}=23.0$ horizon, with this lying just below the cold tongue in the NINO3 region $\left(90^{\circ} \mathrm{W}-150^{\circ} \mathrm{W}, 5^{\circ} \mathrm{S}-5^{\circ} \mathrm{N}\right)$. 


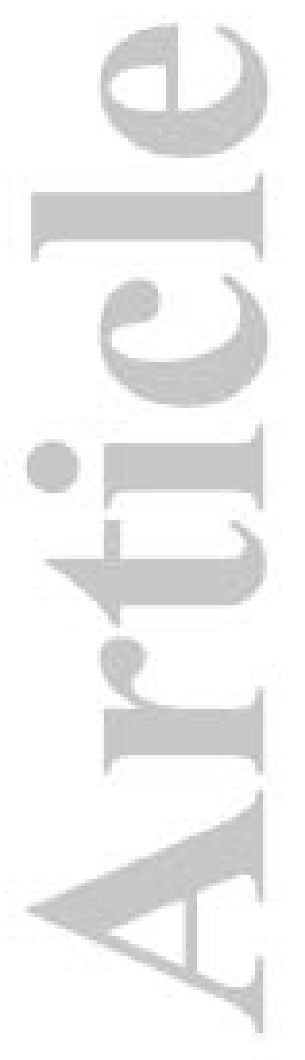

a

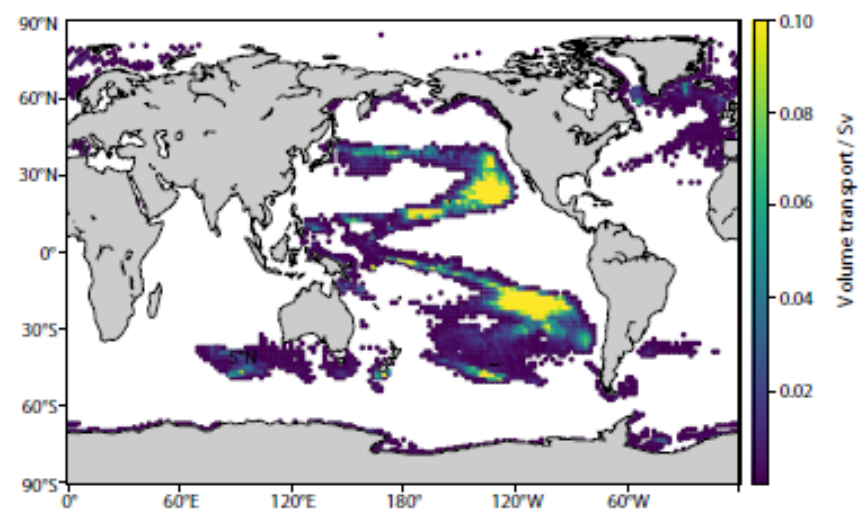

b
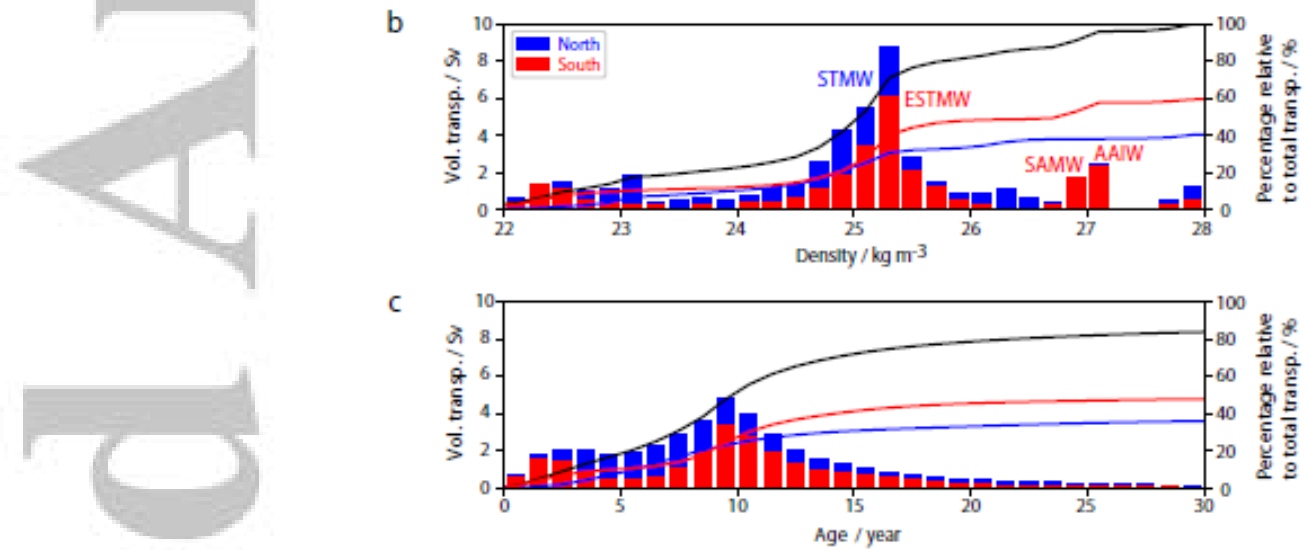

Figure 4. Source waters of the western tropical Pacific Warm Pool that pass through Equatorial Undercurrent across $165^{\circ} \mathrm{E}$ section identified with Lagrangian diagnostics. (a) Geographical distribution of the origins (downward crossing of surface mixed layer base) of Warm Pool waters with the volume transport shown in the color scale with Eastern Subtropical Mode Water formation regions falling within the local maxima of both hemispheres. (b) Histogram of density of original waters in the Northern Hemisphere (blue) and in the Southern Hemisphere (red) when they crossed the base of the surface mixed layer, and (c) travel times from the EUC at the $165^{\circ} \mathrm{E}$ section back to the base of mixed layer in the source region. The analysis in (a) and (b) reveal that there are three principal source contributors to the Equatorial Undercurrent: (i) Eastern Subtropical Mode Water from the Southern Hemisphere, (ii) the grouping of Eastern Subtropical Mode Water and Western Subtropical Mode Water in the North Pacific, and the grouping of Subantarctic Mode Water and Antarctic Intermediate Water from the Southern Ocean.

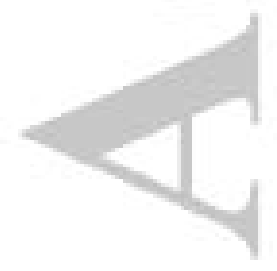



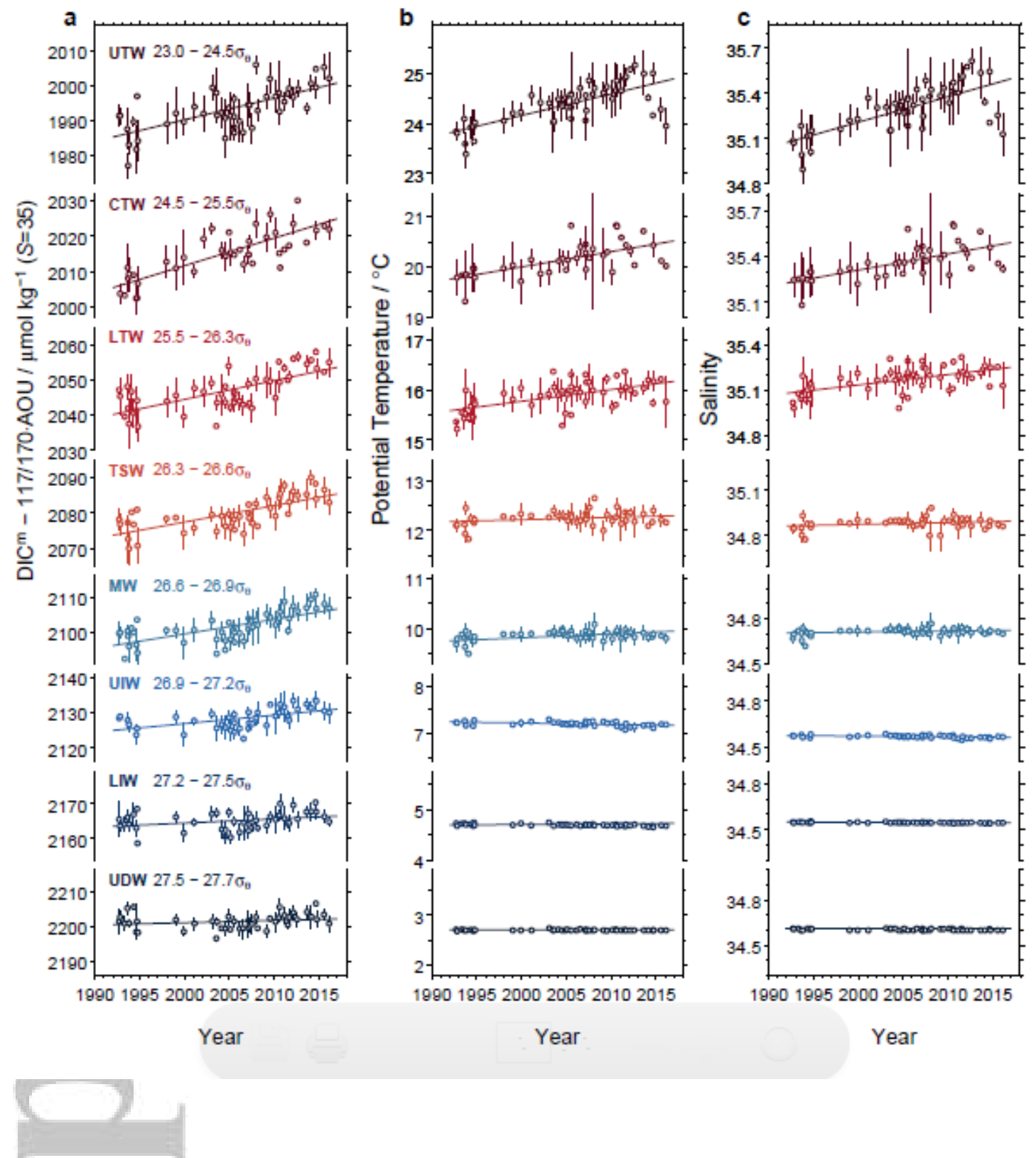

Figure 5. Trends on isopycnal layers in the Equatorial Undercurrent (EUC) for the years 1992-2016. (a) Salinity-normalized respiration-corrected DIC (DIC ${ }^{\mathrm{m}}-\Delta C_{\text {org }}$ ), (b) potential temperature, and (c) salinity. These trends were analyzed for the western Pacific equatorial band $\left(130^{\circ} \mathrm{E}-180^{\circ}, 1^{\circ} \mathrm{S}-1^{\circ} \mathrm{N}\right)$ on eight discrete layers in the EUC and below (see Section 2.2 and 2.3). Each data plot and its error bar denote cruise-mean value and its standard deviation, respectively. 